\title{
Comment And Response Document FOR the Final ReMEdial Action PLAN AND SITE DESIGN FOR STABILIZATION OF THE INACTIVE URANIUM MILL TAILINGS Sites AT SLICK ROCK, Colorado
}

September 1995

DISCLAIMER

This report was prepared as an account of work sponsored by an agency of the United States Government. Neither the United States Government nor any agency thereof, nor any of their employees, makes any warranty, express or implied, or assumes any legal liability or responsibility for the accuracy, completeness, or usefulness of any information, apparatus, product, or process disclosed, or represents that its use would not infringe privately owned rights. Reference herein to any specific commercial product, process, or service by trade name, trademark, manufacturer, or otherwise does not necessarily constitute or imply its endorsement, recommendation, or favoring by the United States Government or any agency thereof. The views and opinions of authors expressed herein do not necessarily state or reflect those of the United States Government or any agency thereof.

DISTRIBUTION OF THIS DOCUMENT IS UNLIMITEP(MP)

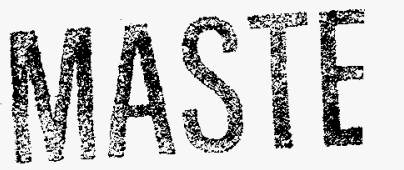




\section{DISCLAIMER}

Portions of this document may be illegible in electronic image products. Images are produced from the best available original document. 
REV. 0

COMMENT AND RESPONSE DOCUMENT FOR THE

FINAL REMEDIAL ACTION PLAN AND SITE DESIGN

FOR STABILIZATION OF THE INACTIVE URANIUM MILL TAILINGS

SITES AT SLICK ROCK, COLORADO

September 1995

Prepared for

U.S. Department of Energy

Environmental Restoration Division

UMTRA Project Team

Albuquerque, New Mexico

Prepared by

Jacobs Engineering Group Inc.

Albuquerque, New Mexico 


\section{COMMENT}

Site: Slick Rock, Colorado Date: 28 July 1994

Document: Final Remedial Action Plan

Reviewer: U.S. Nuclear Regulatory Commission (NRC)

Comment: $\underline{1 \mathrm{~A}}$

DOE should update the earthquake database (at least through 1993)....

\section{RESPONSE}

Page: By:

G. Lindsey (TAC)

Date: 9 August 1994

Comment acknowledged.

Plans for Implementation

An earthquake database dated 1994 has been incorporated in Attachment 2 (see Table 2.4). 
UMTRA DOCUMENT REVIEW FORM

\section{COMMENT}

Site: Slick Rock, Colorado Date: 28 July 1994

Document: Final Remedial Action Plan

Reviewer: U.S. Nuclear Regulatory Commission (NRC)

Comment: 1B

DOE should... and use more recent techniques in the determination of horizontal acceleration.

\section{RESPONSE}

Page: By:

Comment acknowledged.

\section{Plans for Implementation}

Section 1.0 of Attachment 2 has been revised to include the following:

"In a recent study by Keaton (1994a), the attenuation relationship of Campbell (1981) which has been used for UMTRA seismic hazard analysis through 1993, was compared with more recent relationships to determine if it is still applicable with the current state of the art. Other comparative studies were consulted, such as Campbell (1985), Joyner and Bore (1988), and Johnston et al. (1992). Keaton interviewed several key authors and assessed comparisons of methodology and conservatism with more recent relationships that included Boore and Joyner (1994) and Frankel et al. (1994). There are differences in the philosophical approaches of these studies. Boore et al. believe that the shape of the attenuation relationship is independent of earthquake magnitude, whereas Campbell and Bozorgnia (1994) believe that the shape is magnitude-dependent. The conclusion of this comparison, supported by attenuation curves for each study, is that Campbell (1981) is reasonable and appropriate, even though the database was smaller. However, because of the history of support for Campbell in DOE, NRC, and TAC, it is appropriate that DOE adopt the enhancements and refinements contained in Campbell and Bozorgnia (1994). A copy of the study and conclusions by Keaton is available from the Albuquerque Office of DOE." 


\section{UMTRA DOCUMENT REVIEW FORM}

\section{COMMENT}

Site: Slick Rock, Colorado Date: 28 July 1994

Document: Final Remedial Action Plan

Reviewer: U.S. Nuclear Regulatory Commission (NRC)

Comment: $\underline{2}$

DOE should provide support for the demonstration of the absence of Quaternary faulting and demonstrate (through existing references) a definitive age (years before present) of Pleistocene and/or Holocene for the Quaternary deposits not offset by the underlying non-tectonic faults.

\section{RESPONSE}

Page: By:

The text has been revised to emphasize that Quaternary faulting is acknowledged although none was observed. The age of the faulting is inconsequential where present activity is assumed and has been incorporated in the seismic design. The nontectonic features are described as presently active, and related activity is primarily by creep rather than by rupture. The maximum seismicity (magnitude 4.0 to 5.0 ) is assumed for design purposes.

\section{Plans for Implementation}

The text was revised to provide a discussion on the evidence for Quaternary faulting and includes published references regarding the age of the deposits overlying the salt core collapse features. 


\section{COMMENT}

Site: Slick Rock, Colorado Date: 28 July 1994

Document: Final Remedial Action Plan

Reviewer: U.S. Nuclear Regulatory Commission (NRC)

Comment: $\underline{3 A}$

DOE should clarify the manner of assignment of different magnitudes 15.7 for the Burro Canyon site and 7.0 for the Naturita site) for the same structure (Big Gypsum valley) and the determination as to which ME should be used. DOE should provide a technical basis for the statement that the 6.2 earthquake is the threshold magnitude at which ground rupture occurs. DOE should discuss the methodology used to describe how the maximum earthquake values in Figure 2.7 were drawn.

\section{RESPONSE}

Page: By:

The confusion arises from two characteristics of the salt core anticlines: 1) different interpretations of the continuity of mapped fault segment lengths within the nontectonic structure of the collapsed salt core anticline; and 2) as discussed in the Naturita and Slick Rock RAPs, all of the nontectonic salt core collapse features mask an underlying basement fault whose last known movement was probably during deposition of the Permian-aged Paradox salt.

The fault segments are largely inferred from the relief and configuration of the graben because the actual trace is buried below valley colluvium. The different interpretation of fault lengths based on aerial photographic interpretation, as well as from published maps, is shown on the respective fault maps (Plate 2.1) of the respective documents. The possible Quaternary age of the fault traces that are exposed lead to the more conservative approach in the Naturita RAP that the inferred mapped fault traces are included in the total length of the segments.

As stated in Section 4.1 of both the Naturita and Slick Rock RAPs, the procedure of determining fault magnitude by the fault length is based on Bonilla et al. (1984). As discussed on page 4-4 of the Naturita RAP, the magnitude was based on the fault lengths as an expression of the (underlying) tectonic features for the criticality assessment performed in Figure 4.1. This was a more conservative approach than was taken in the Slick Rock RAP (also page 4-4) that considered the faults as nontectonic features and considered only their mapped lengths in estimating the potential magnitudes. Both approaches are valid but inconsistent within UMTRA documentation. 
COMMENT AND RESPONSE DOCUMENT FOR THE FINAL

A more practical approach is a third method, which uses the assessment of Kirkham and Rogers (1981) that it is unlikely that the salt core anticline collapse features are capable of generating more than a 4.0 or 5.0 magnitude earthquake. This assessment is supported by a theory of Campbell (1984) that where rupture of the crystalline basement rock is not involved, the maximum magnitude of such events is very likely $M=5.5$ or less. Campbell concludes that the basement rock provides the primary seismogenic source in larger earthquakes, and it is unlikely that stresses within the sedimentary material contribute any substantial energy to ground motion. This approach concludes that the basement faults of the Paradox folded belt within the site region are not capable in the present seismotectonic regime; however, the nontectonic salt anticline collapse structures are considered active. The fault length/magnitude relationships are not applicable to the nontectonic structures so that the potential magnitude of each structure is considered to be in a range of 4.0 or 5.0 (Kirkham and Rogers, 1981). The noncapable designation of basement faults in the folded belt is based on the lack of surface expression, since they are fully marked by the salt anticline features, and the lack of association of seismic activity with any faults in the region except within the Uncomphagre Uplift. In lieu of evidence of the presence of a design tectonic fault within this province, the potential acceleration of adjacent seismotectonic provinces will be compared with the floating earthquake, as defined in Section 1.0, to determine the design acceleration.

\section{Plans for Implementation}

Section 2.4 of Attachment 2 has been revised to include this discussion and show a maximum earthquake magnitude of all faults related to the Paradox Basin salt core collapse features of $M=5.0$ regardless of mapped fault length. For consistency, the Naturita RAP will be similarly revised. 


\section{COMMENT}

Site: Slick Rock, Colorado

Date: 28 Julv 1994

Document: Final Remedial Action Plan

Reviewer: U.S. Nuclear Regulatory Commission (NRC)

Comment: $\underline{3 B}$

DOE should provide a technical basis for the statement that the 6.2 earthquake is the threshold magnitude at which ground rupture occurs.

\section{RESPONSE}

Page: By:

Comment acknowledged.

\section{Plans for Implementation}

Section 1.1 of Attachment 2, which discusses the determination of the floating earthquake, has been revised to clarify the technical basis for the use of magnitude 6.2 as the floating earthquake. The 1985 UMTRA Project documentation citing the DOE-NRC agreement to adopt the magnitude 6.2 earthquake as a floating earthquake magnitude has been included in the references. 


\section{COMMENT}

Site: Slick Rock, Colorado

Date: 28 Julv 1994

Document: Final Remedial Action Plan

Reviewer: U.S. Nuclear Regulatory Commission (NRC)

Comment: $3 \mathrm{C}$

DOE should discuss the methodology used to describe how the maximum earthquake values in Figure 2.7 were drawn.

\section{RESPONSE}

Page: By:

Comment acknowledged.

\section{Plans for Implementation}

The paragraph on Graphical determination of ME in Section 2.4 of Attachment 2 was revised to clarify the determination of the maximum earthquake. The intent of Figure 2.7, to show that the historic data are inadequate for this determination, is unnecessary; therefore, it was deleted. 


\section{COMMENT}

Site: Slick Rock, Colorado Date: 28 July 1994

Document: Final Remedial Action Plan

Reviewer: U.S. Nuclear Regulatory Commission (NRC)

Comment: $\underline{4 A}$

DOE should discuss and provide figures, as appropriate, regarding the RAP statement that hydrocarbon exploration has occurred adjacent to the site. The potential for hydrocarbon production in the site area and the effect of such production on the integrity of the disposal cell should be addressed, including the potential for collapse of the strata overlying the production horizon(s).

\section{RESPONSE}

Page: By:

Date: 9 August 1994

Comment acknowledged.

\section{Plans for Implementation}

Sections 2.5 and 5.4 of Attachment 2 were revised to include a discussion on the findings of the nearby exploratory gas well, the potential for finding petroleum resources, and the possible effects of production of nearby oil and gas.

The potential for subsidence due to production of hydrocarbons in the near vicinity of the site will also be of similar negligible impact because of the integrity of the bedrock formations overlying potential production zones. The potential production zones would be expected to be within the Permian or Pennsylvanian strata, or older rocks, which are not exposed on the surface within this folded belt region. Since there are no faults in the immediate vicinity of the site that would be the focus of differential displacement, any subsidence resulting from oil or gas production would be fairly uniformly distributed over the surrounding area. Other factors that would mitigate effects of subsidence due to any nearby production is the relatively small acreage of the disposal site, compared to the area of a production zone, and the thickness of the cell cover that is designed to provide protection against cover cracking. 


\section{COMMENT}

Site: Slick Rock, Colorado Date: 28 July 1994

Document: Final Remedial Action Plan

Reviewer: U.S. Nuclear Regulatory Commission (NRC)

Comment: $\underline{4 B}$

DOE should provide an oil/gas well location map and text to include both exploration and exploitation wells, as well as seismic surveys within a $9.3 \mathrm{mi}(15 \mathrm{~km})$ radius of the site.

\section{RESPONSE}

Page: By:

Comment acknowledged.

\section{Plans for Implementation}

The location of known oil and gas exploration wells within a 9-mile site radius has been included in Section 2.5 of Attachment 2, as well as a discussion of related data available from the state Geological Survey of Mines and Mineral Resources.

The potential for subsidence due to production of hydrocarbons in the near vicinity of the site will also be of similar negligible impact because of the integrity of the bedrock formations overlying potential production zones. The potential production zones would be expected to be within the Permian or Pennsylvanian strata, or older rocks, which are not exposed on the surface within this folded belt region. Since no faults in the immediate vicinity of the site would be the focus of differential displacement, any subsidence resulting from oil or gas production would be fairly uniformly distributed over the surrounding area. Other factors that would mitigate effects of subsidence due to any nearby production are the relatively small acreage of the disposal site, compared to the area of a production zone, and the thickness of the cell cover that is designed to provide protection against cover cracking. 


\section{COMMENT}

Site: Slick Rock, Colorado Date: 28 July 1994

Document: Final Remedial Action Plan

Reviewer: U.S. Nuclear Regulatory Commission (NRC)

Comment: $\underline{\underline{5}}$

DOE should adopt those natural resource portions (potash, natural brines) of the Naturita RAP (DOE, 1993) that are equally applicable to the Burro Canyon site.

\section{RESPONSE}

Page:

$$
\text { By: }
$$

Comment acknowledged.

\section{Plans for implementation}

Section 2.5 of Attachment 2 was revised to include a discussion of the potential for potash and natural brines mineral resources of the Paradox Salt Basin relative to the site. Figure 2.5, which is used to demonstrate geologic structure, also shows the limits of the potash deposits and was referenced. 


\section{COMMENT}

Site: Slick Rock, Colorado Date: 28 Julv 1994

Document: Final Remedial Action Plan

Reviewer: U.S. Nuclear Regulatory Commission (NRC)

Comment: $\underline{6}$

DOE should include the planned additional consolidation testing of off-pile and subpile materials.

\section{RESPONSE}

Page: By:

Off-pile and subpile contaminated materials from NC and UC sites are low-plasticity silt, clay and sandy clayey silt (ML, CL, SM, SC). These materials, along with $U C$ and NC tailings (which are sand), will be placed in the disposal cell at least 90 percent of the maximum dry density and at drier than optimum moisture content. The degree of saturation of compacted nontailings material will be about 45 percent. The consolidation parameters selected in the settlement calculation (Calculation No. 11-323-01-01) are from one consolidation test on a saturated sample and therefore yields very conservative results. Actually, a major part of the settlement will be due to immediate (elastic) settlement which will occur before placement of the cover. In addition, since all contaminated materials will be compacted, the differential settlement will be minimal. Since the materials will be unsaturated and compacted, consolidation test results do not reflect the actual conditions. Therefore, no additional consolidation testing is required and the statement in the calculation was deleted.

\section{Plans for Implementation}

None required. 


\section{COMMENT}

Site: Slick Rock, Colorado

Date: 28 Julv 1994

Document: Final Remedial Action Plan

Reviewer: U.S. Nuclear Regulatory Commission (NRC)

Comment: $\underline{7}$

Paragraph 3 of Section 3.3.3 in the Remedial Action Selection Report is confusing and should be re-written to more clearly address long-term differential settlement gradients.

\section{RESPONSE}

Page: By:

Comment acknowledged. The details of the settlement and cover cracking analysis, including CONSOL output files, are presented in Attachment 1, Calculation No. 11-323-01-01.

\section{Plans for Implementation}

The confusing statements were deleted from the third paragraph of Section 3.3.3 in an earlier revision of the RAP. 


\section{COMMENT}

Site: Slick Rock, Colorado Date: 28 July 1994

Document: Final Remedial Action Plan

Reviewer: U.S. Nuclear Regulatory Commission (NRC)

Comment: $\underline{8.1}$

Section 02200 of the Specification Article 2.2.B.1.b - Maximum particle size should not exceed $1 / 2$ the compacted lift thickness. As written, the specification allows particle sizes as thick as the compacted lift. This specification is inconductive to achieving compaction.

\section{RESPONSE}

Page: By:

A. M. Banani (RAC)

Date: 9 August 1994

Adequate compaction will be achieved if the maximum particle is up to 12 inches. This has been demonstrated at all the UMTRA Project sites completed to date. Contaminated materials often have particle sizes larger than one-half the layer thickness. Having a size requirement of one-half the layer thickness will unnecessarily require crushing and processing of the materials. Adequate compaction will be achieved with the current specification and no changes are required. The compaction requirement is to compact each lift of materials to at least the minimum densities specified in Article 3.8 of Section 0200 of the specifications. Compaction results will be obtained in the field. Adequate compaction will be achieved with particle sizes as thick as the compacted lift.

\section{Plans for Implementation}

None required. 


\section{COMMENT}

Site: Slick Rock, Colorado

Document: Final Remedial Action Plan

Date: 28 Julv 1994

Reviewer: U.S. Nuclear Regulatory Commission (NRC)

Comment: 8.2

Section 0200 of the Specification, Article 2.2.B.2.b - The paragraph would permit the placement of radon barrier material that has only 30 percent fines. DOE needs to provide additional assurance that radon barrier soils will meet or exceed the quality of those in the radon attenuation model.

\section{RESPONSE}

Page: By:

Comment acknowledged.

At the time, sieve analyses were performed on seven radon barrier samples from Disappointment Valley. These analyses show that two samples, RB2 $(3.5 \mathrm{ft}$ to $9 \mathrm{ft}$ ) and RB-6 ( $0 \mathrm{ft}$ to $3 \mathrm{ft}$ ), are 38 and 30 percent finer than sieve \#200, respectively, and that the remaining samples are more than 50 percent finer than sieve $\# 200$. The two samples were tested for 15 bar moisture content, diffusion coefficient, specific gravity, etc. These samples were among the samples whose properties were used in the radon attenuation model. Calculation No. 11-321-01-00 (Sheet B-3) shows that the diffusion coefficients and long-term moisture contents of these samples are not significantly different from the average properties of all samples used in the radon attenuation model. Therefore, it is not expected that placing radon barrier materials with 30 percent finer than sieve $\# 200$ will change the design radon barrier thickness.

Laboratory testing was conducted on samples of the fine-grained excavated materials at the Burro Canyon disposal site to determine whether this material is suitable for use as radon barrier material. The results indicated that the Burro Canyon material is suitable for use as a radon barrier source, and the decision was made to use this material in place of the Disappointment Valley borrow source.

\section{Plans for Implementation}

Text was revised to reflect the decision to use Burro Canyon excavated materials as the source for radon barrier. 


\section{COMMENT}

Site: Slick Rock, Colorado Date: 28 Julv 1994

Document: Final Remedial Action Plan

Reviewer: U.S. Nuclear Regulatory Commission (NRC)

Comment: $\underline{8.3}$

Section 0200 of the Specification, Article 3.5.C.6 - If the "routing of hauling and spreading units" is insufficient to achieve proper compaction, additional mechanical compaction with alternate equipment will be necessary.

\section{RESPONSE}

Page: _ By: A.M. Banani (RAC) Date: 9 August 1994

The permanent stockpile areas are not supporting any load beyond their own weights, nor does the stockpile location have any impact on the disposal cell performance. The compaction achieved by routing of hauling and spreading equipment units is sufficient to prevent any excessive settlement. In addition, requiring denser compaction may inhibit plant growth and eventual site revegetation.

\section{Plans for Implementation}

None required. 


\section{COMMENT}

Site: Slick Rock, Colorado Date: 28 July 1994

Document: Final Remedial Action Plan

Reviewer: U.S. Nuclear Regulatory Commission (NRC)

Comment: $\underline{8.4}$

Section 02200 of the Specification, Article 3.5.C.7.b - References to $90 \%$ and $95 \%$ compaction should refer to "assumed" or "equivalent" compaction since the actual value cannot be determined.

\section{RESPONSE}

Page: _ By: A. M. Banani (RAC) _ Date: 9 August 1994

The DOE concurs with the comments. The intent was for compacting large-size materials placed within zones requiring 90 or 95 percent compaction.

\section{Plans for Implementation}

In the next revision to specifications in the RAP, the title refers to "equivalent" compaction. 


\section{COMMENT}

Site: Slick Rock, Colorado

Date: 28 July 1994

Document: Final Remedial Action Plan

Reviewer: U.S. Nuclear Regulatory Commission (NRC)

Comment: $\underline{8.5}$

Section 02200 of the Specification, Article 3.7.A - Areas excavated to bedrock or to cobbles/gravel should not require subgrade preparation provided that they are judged to be free of loose, compressible, or otherwise unsatisfactory materials. Additional language should be added to require confirmation of the integrity of bedrock and cobbles/gravel subgrades.

\section{RESPONSE}

Page: By:

All areas excavated to bedrock or to cobbles/gravel, except as noted in Section 3.7.C, will be in off-pile areas. Backfill and compaction in these areas will not affect the performance of the cell. Prior to placing fill over areas excavated to bedrock or cobbles/gavels, the exposed surface shall be inspected by the contractor. Areas that require subgrade preparation shall be compacted as specified in Section 3.7.B.

\section{Plans for Implementation}

None required. 


\section{UMTRA DOCUMENT REVIEW FORM}

\section{COMMENT}

Site: Slick Rock, Colorado

Date: 28 July 1994

Document: Final Remedial Action Plan

Reviewer: U.S. Nuclear Regulatory Commission (NRC)

Comment: $\underline{9}$

DOE needs to provide the Remedial Action Inspection Plan for NRC review and concurrence.

\section{RESPONSE}

Page: _ By: M. B. Leaf (TAC) Date: 21 October 1994

Comment acknowledged.

\section{Plans for Implementation}

Since this comment was made, the NRC and DOE have reviewed the RAIP through Revision O, Review D. 


\section{COMMENT}

Site: Slick Rock, Colorado

Document: Final Remedial Action Plan

Date: 28 July 1994

Reviewer: U.S. Nuclear Regulatory Commission (NRC)

Comment: 10

DOE must demonstrate compliance with EPA's final ground water clean-up standards in 40 CFR 192, Subparts $B$ and C.

\section{RESPONSE}

Page: By:

Date: 21 August 1994

The DOE has deferred ground water cleanup to a separate phase of the UMTRA Project. During surface remediation, the tailings and other residual radioactive materials (RRM) will be removed from the processing sites, thereby removing the source of contamination. The DOE is responsible for demonstrating that cleanup or control of existing, processing-related ground water contamination at the existing Slick Rock processing sites complies with the final EPA ground water protection standards in 40 CFR Part 192, Subpart B (60 FR 2854). The DOE has decided that ground water compliance will be addressed under a separate DOE program, which will comply with the requirements of the National Environmental Policy Act. Future site characterization investigations will be conducted as necessary to determine the appropriate ground water compliance strategy. Decoupling the surface remedial action phase of the UMTRA Project (Subpart A) from the ground water compliance phase (Subparts $B$ and $C$ ) will not adversely affect human health and the environment, because the source of contamination will be removed.

Information on the current and future water uses in the vicinity of the processing sites is provided in the response to NRC Comment 12.

\section{Plans for Implementation}

None. Decoupling the surface remedial action phase (Subpart A) with the ground water compliance phase (Subparts $B$ and $C$ ) is discussed in Attachment 4, Section 4.0, as well as in Sections 5.6, 5.6.1, and 5.6.2 of the Remedial Action Selection Report. 


\section{COMMENT}

Site: Slick Rock, Colorado Date: 28 Julv 1994

Document: Final Remedial Action Plan

Reviewer: U.S. Nuclear Regulatory Commission (NRC)

Comment: 11

DOE has indicated that additional laboratory experiments (batch and/or column leaching tests) are needed to evaluate adsorption reactions in soils beneath the disposal cell.

\section{RESPONSE}

Page: By: A. Groffman, J. Crain (TAC)

Date: 22 August 1994

Reevaluation of batch and column tests indicates the existing data provide sufficient information to characterize the subsurface with respect to the interaction of tailings pore fluids and solid phases of the Burro Canyon Formation. Results from three point sorption batch experiments performed with synthetic leachate, spiked with cadmium, molybdenum, selenium, and uranium, and Burro Canyon fine-grained materials were used to calculate partitioning coefficients $\left(K_{d}\right)$, contaminant-specific retardation velocities, and travel times through the subsurface. The above constituents have been identified as constituents of potential concern in the baseline risk assessment for the Slick Rock sites (DOE, 1994). Partitioning coefficient values for more mobile constituents such as chloride, sulfate, and nitrate have also been derived. These data provide information about migration of cations and anionic species including oxyanions of redox sensitive elements (i.e., sulfate, selenate, and molybdate in the environment beneath the proposed cell). Furthermore, results from composite column tests constructed to reflect the stratigraphy beneath the site have also been evaluated. Although equilibrium conditions were never attained in the columns, this information provides valuable insight into predicting the transport and behavior of individual contaminants in the subsurface.

A thorough analysis of solid phases in the Burro Canyon Formation has also been performed to illuminate some of the possible rock/solute interactions. Data such as mineral identification, ion exchange capacity, and composition of mineral surface coating were used in the final analysis of solid phase/solute interaction in the subsurface.

In addition to geochemical parameters, BET surface area measurements of the clay fraction of the Burro Canyon Formation material have been determined. These data have been used to evaluate the potential surface area that may come into contact with fluids in the subsurface. 
In summary, the Burro Canyon Formation in the vicinity of the site has been adequately characterized with respect to the behavior and attenuation of constituents germane to uranium mill tailings leachate. Geochemical analysis, along with results from batch and column sorption tests performed in the past, are sufficient to provide input to hydrological models and to assess the potential for the migration of contaminants beneath the disposal cell.

\section{Plans for Implementation}

None required. 


\section{COMMENT}

Site: Slick Rock, Colorado Date: 28 July 1994

Document: Final Remedial Action Plan

Reviewer: U.S. Nuclear Regulatory Commission (NRC)

Comment: 12

DOE must provide information on the current source(s) of the municipal and domestic water supply for the town of Slick Rock and the vicinity surrounding the processing sites. This information should be in the form of a text description of the municipal water supply and a map showing the locations of the identified private wells within a 2 -mile radius of the sites. DOE must also provide an evaluation of the future projected water use in the vicinity of the processing sites.

\section{RESPONSE}

Page: By: $\quad$ K. Monks (TAC)

Date: 2 August 1994

No municipal water supplies exist for the community of Slick Rock, which consists of a combination restaurant/general store. No one currently lives at or close to (within 0.25 mile [mi] [1.6 kilometer $\{\mathrm{km}\}]$ of) the UC or NC sites. About 10 people, including residents in two trailers in the vicinity of the community, live within $10 \mathrm{mi}$ $(16 \mathrm{~km})$ of the UC and NC sites. There are no schools in Slick Rock.

Two domestic wells are currently used within a $2-\mathrm{mi}(3-\mathrm{km})$ radius of the former processing sites, as discussed in Attachment 3. Section 3.1.9. The approximate locations of all private wells (active and inactive) are shown on Figure 3.1 (Attachment 3).

Water use in the vicinity of the former processing sites is anticipated to increase during remedial action construction. M-K Environmental Services (MK-ES) reports that most of the construction water from the retention basin will be used for dust control within the UC site and that approximately 1.2 acre-feet (ac-ft) $\left(9.7 \times 10^{-4}\right.$ cubic meters $\left[\mathrm{m}^{3}\right]$ ) of water per month will be used during construction at the UC site, based on the actual water consumption for dust control at previously constructed UMTRA Project sites. Remedial action construction is scheduled to occur from April to November and will be shut down during winter.

Water use is anticipated to decrease significantly following remedial action construction. A detailed evaluation of projected water use has been deferred until the UMTRA Project ground water compliance program for Slick Rock is under way. 


\section{Plans for Implementation}

A paragraph was added to the beginning of Section 5.1 .5 of the Remedial Action Selection Report and Section 3.1.9 of Attachment 3 stating that there is no municipal water supply for the community of Slick Rock. The locations of the identified private wells are shown on Figure 3.1 in Attachment 3. 


\section{COMMENT}

Site: Slick Rock, Colorado

Date: 28 July 1994

Document: Final Remedial Action Plan

Reviewer: U.S. Nuclear Regulatory Commission (NRC)

Comment: 13

DOE must provide evidence through water-quality measurements or potentiometric measurements in the vicinity of the NC site to support the assumption that the Dolores River provides a hydraulic barrier between the tailings site and the identified private wells on the opposite side of the river.

\section{RESPONSE}

Page:

By: $\quad$ K. Monks (TAC)

Date: 2 Auqust 1994

The DOE has determined that the level of characterization at the former processing sites is adequate for surface remedial action since the tailings are being relocated to the Burro Canyon disposal site. The DOE agrees with the NRC that additional site characterization (water level and quality measurements) will be necessary to support the assumption that the private wells on the north side of the Dolores River are hydrologically separated from residual ground water contamination from the NC tailings; information currently is insufficient to definitely support this assumption. However, these additional site characterization activities are not necessary for the surface remedial action phase (Subpart A of 40 CFR Part 192) and will be deferred to the ground water compliance phase (Subparts B and C of 40 CFR Part 192) of the UMTRA Project.

Of the three wells located across the Dolores River from the NC site, only one private well is useable. The ground water quality of this well was tested in February 1994; the results showed that all of the potentially hazardous constituents measured (arsenic, barium, cadmium, chromium, lead, molybdenum, net gross alpha, nitrate, radium-226 plus radium-228, selenium, and uranium) were below their respective maximum concentration limits (MCLs).

\section{Plans for Implementation}

None. 


\section{COMMENT}

Site: Slick Rock, Colorado

Date: 28 July 1994

Document: Final Remedial Action Plan

Reviewer: U.S. Nuclear Regulatory Commission (NRC)

Comment: 14

DOE should reference documentation, such as State or Dolores County studies on population projections, that support the statement in Attachment 3 of the RAP that "Groundwater development in the vicinity of the disposal site should not increase over the next 50 years."

\section{RESPONSE}

Page: By:

According to communications with the Colorado Department of Local Affairs, Division of Local Government, the population projections for San Miguel County, Colorado, are as follows:

$\begin{array}{ll}1990 & 3682 \\ 1995 & 3977 \\ 2000 & 4441 \\ 2005 & 4881 \\ 2010 & 5346 \\ 2015 & 5835 \\ 2020 & 6333\end{array}$

This is a projected increase of 2356 people from 1995 to 2020 , or a 60 percent increase over the next 15 years.

No information is available about where the population would increase within the county, although a reasonable conclusion is that projected population increases are believed to occur in the Telluride area. This population projection neither supports nor denies the statement about ground water development in the vicinity of the disposal site. However, land use around the cell (i.e., BLM grazing land) better supports this conclusion.

\section{Plans for Implementation}

None. Section 3.2.6 of Attachment 3 was revised as requested. 


\section{COMMENT}

Site: Slick Rock, Colorado Date: 28 Julv 1994

Document: Final Remedial Action Plan

Reviewer: U.S. Nuclear Regulatory Commission (NRC)

Comment: $\underline{15}$

DOE should recalculate the seepage flux analysis in Calculation No. 11-93-12-06-00, using a realistic and conservative estimate for the bottom seepage rate. The analysis does not mention how the $1 \times 10^{-6} \mathrm{~cm} / \mathrm{s}$ value was deemed representative. It appears that the value was selected as the median of packer test permeabilities. Borehole packer tests are designed to measure the horizontal component of permeability. The analysis utilizes the vertical permeability component. Layered earth materials commonly exhibit a distinct anisotropy between the horizontal $\left(K_{h}\right)$ and vertical $\left(K_{v}\right)$ permeability components, with the horizontal component generally being the larger. The anisotropy ratio $K_{h} / K_{v}$ can be 10:1 in some materials, and as high as 100:1 in other. A reevaluation of this calculation must also address any impacts to the longterm moisture accumulation scenario and potential adverse impacts to seepage through the sandstone layers exposed in the excavation sidewalls.

\section{RESPONSE}

Page: _ By: J. Crain (TAC) Date: 4 August 1994

The very low permeabilities presented in the draft seepage report were determined from laboratory tests of unweathered rock samples obtained, in most cases, well below the interface of the Dakota Sandstone and the Burro Canyon Formation. As the current excavation will not be advanced into the unweathered Burro Canyon Formation, all references to the laboratory determined permeabilities were deleted from the seepage report. The $10^{-8} \mathrm{~cm} / \mathrm{s}$ conductivity reported in the document was determined from a packer test of a zone of the Burro Canyon Formation also located considerably below the planned excavation depth.

The higher values of conductivity, those in the $10^{-4}$ to $10^{-6} \mathrm{~cm} / \mathrm{s}$ range, were determined by packer tests of the fine-grained strata of the Dakota Sandstone and Burro Canyon Formation (weathered layers) near the interface of the two formations. As the bottom of the disposal cell will be located near the interface of the Dakota Sandstone and Burro Canyon Formation, selecting a lower boundary flux of $10^{-6} \mathrm{~cm} / \mathrm{s}$ as a model input parameter is appropriate, and the simulated results are suitably conservative for disposal cell design purposes.

The representative section (for the computer simulation) is a profile of the southern end of the disposal cell where both the excavation depth and the thickness of 
COMMENT AND RESPONSE DOCUMENT FOR THE FINAL

contaminated materials are greatest. As the NC and UC tailings are mostly uniform sand and sandy-clayey gravel, and the disposal cell bottom slope is descending from north to south, the conjecture is that if a saturated zone does develop, it will develop at the low point (southern end) of the disposal cell excavation. Because the finegrained strata of the Dakota Sandstone and Burro Canyon Formation at the bottom of the excavation are not exposed downdip of the site, a surface expression (seep) caused by water moving laterally from the disposal cell will not develop. Thus, contaminated water can move laterally through the fine-grained strata of the Dakota Sandstone and Burro Canyon Formation without impacting human health and the environment. As to the predicted height of the saturated zone, even if the bottom of the model profile was coded as a "no-flow boundary" and side nodes near the bottom of the profile were coded to allow water to exit horizontally, the height and duration of the saturated zone would be unchanged.

At the time the seepage report was written, the precise depths of the locally uniform sandstone layers of the Dakota Sandstone (designated $\mathrm{Kd} 1$ and $\mathrm{Kd} 2$ ) were unknown. A more complete characterization of the disposal site stratigraphy was established using the data collected during a November 1993 drilling and test-pit program, and the precise depths of $\mathrm{Kd} 1$ and $\mathrm{Kd} 2$ were determined using both the November 1993 data and data collected during previous field efforts. The bottom of the lowest sandstone layer ( $\mathrm{Kd} 1$ ) is over 10 meters above the bottom of the excavation at the southern end of the disposal cell. If all the contaminated materials were placed at optimum water content (see seepage report), the predicted height of the saturated zone would be up to $6 \mathrm{~m}(20 \mathrm{ft})$ below the $\mathrm{Kd} 1$ layer.

An additional calculation was performed by the TAC (Calculation No. SRK-09-94-1201-00) to further demonstrate the conservatism inherent in the planned excavation depth. Also, the RAC, in accord with DOE direction, modified the design plans and specification to ensure that water addition to the RRM is strictly controlled. Changes to the plans and design specifications include: 1) the use of fine-spray nozzles on all water trucks to control dust without raising the moisture content of contaminated material; 2) no water addition to sand tailings for compaction (60 to 70 percent of the disposal cell volume is sand tailings); 3) fine-grained contaminated material will be placed at drier than optimum moisture content; and 4) installation of a water collection system (likely a standpipe and pump) at the lowest (southern) end of the disposal cell.

\section{Plans for Implementation}

The seepage report (Calculation No. SRK-11-93-12-06-00) has been superseded by Calculation No. SRK-09-94-12-01-00 in Appendix C of Attachment 3 of the RAP. 


\section{COMMENT}

Site: Slick Rock, Colorado Date: 28 July 1994

Document: Final Remedial Action Plan

Reviewer: U.S. Nuclear Regulatory Commission (NRC)

Comment: 16

DOE should provide the stated numerical simulation (Attachment 3, page 3-51) of the upper sandstone as a calculation set in the RAP, and reference it as the demonstration that the uppermost aquifer at the disposal site cannot provide a sustained yield of $150 \mathrm{gpd}$.

\section{RESPONSE}

Page: By:

Comment acknowledged.

Plans for Implementation

The requested information was provided in Section 3.2.4 of Attachment 3. 


\section{UMTRA DOCUMENT REVIEW FORM}

\section{COMMENT}

Site: Slick Rock, Colorado

Date: 28 July 1994

Document: Final Remedial Action Plan

Reviewer: U.S. Nuclear Regulatory Commission (NRC)

Comment: 17

NRC staff considers that visual inspection of potential seeps is inadequate to demonstrate that the cell is performing as designed. Visual inspection of potential seeps at a distance of potentially 100 meters of more from the disposal cell does not provide the earliest practicable verification of cell performance. DOE should develop a monitoring plan that demonstrates cell performance in a more direct manner. An approach, such as monitoring the saturation level in the tailings through standpipes, would provide the earliest verification of cell performance.

\section{RESPONSE}

Page: By: $\quad$ K. Monks (TAC)

Date: 2 Auqust 1994

Comment acknowledged.

\section{Plans for Implementation}

The RAP was revised to include 1) the installation of standpipes at the toe of the disposal cell to drain any accumulating water during the remedial action, and 2) the installation of a minimum of one piezometer in the Dakota Sandstone at the toe of the cell to monitor the lateral movement of tailings pore fluids. 


\section{COMMENT}

Site: Slick Rock, Colorado Date: 28 July 1994

Document: Final Remedial Action Plan

Reviewer: U.S. Nuclear Regulatory Commission (NRC)

Comment: 18

DOE must provide minus 15 bar capillary suction measurements of the UC offpile and subpile material to confirm that a conservative long-term moisture value has been chosen for the model.

\section{RESPONSE}

Page: By:

The UC subpile and offpile materials are low-plasticity silt, clay, and clayey silty sand materials. Forty-seven percent of the material is finer than sieve $\# 200$ (Calculation No. 11-250-04-03). The volume-weighted average in situ moisture content of these materials from 28 tests is 9.4 percent with SEN of about 2 .

In general, long-term moisture content can be estimated either by minus 15 bar capillary suction measurements or by empirical correlations. Minus 15 bar moisture contents for UC subpile and offpile materials are not available. However, minus 15 bar moisture contents for similar soils are usually higher than 9.4 percent. For example, minus 15 bar moisture content of radon barrier material, which has physical properties very similar to UC subpile and offpile material, is 15.5 percent (Calculation No. 11-321-01-00). The empirical relationship using rainfall data and soil type shows that the estimated long-term moisture content of UC subpile and offpile materials is the same as average in situ moisture content (i.e., 9.4 percent) (see next sheet).

A sensitivity analysis was performed to determine the effects of variations of the long-term moisture contents of subpile and offpile materials on radon barrier thickness. This analysis shows that decreasing the long-term moisture content of UC subpile and offpile materials to 6 percent and using corresponding diffusion coefficient (from sheets 27 to 30 of Calculation No. 11-340-01-00) increases the radon barrier thickness from $61 \mathrm{~cm}$ to $62 \mathrm{~cm}$. Therefore, the thickness of the radon barrier is only slightly sensitive to variations in long-term moisture contents of UC subpile and offpile materials (see attached sheets).

\section{Plans for Implementation}

No further action is required. 
COMMENT AND RESPONSE DOCUMENT FOR THE FINAL

REMEDIAL ACTION PLAN AND SITE DESIGN FOR STABILIZATION OF THE

USS. NUCLEAR REGULATORY COMMISSION (NRC)

Estimating Long -Term Moisture Content of $U C$ Subpile and off pile Materials

$$
\begin{aligned}
& m_{r}=\left(0.124 P_{p}^{0.5}-0.001 E_{v}-0.04+0.156 f_{c m}\right) \\
& \omega_{r}=m_{r}\left(\frac{\gamma_{\omega}}{\gamma_{d}}-\frac{1}{c_{s}}\right)
\end{aligned}
$$

Where,

$m_{p}=$ residual fraction of moisture saturation

$\omega_{r}=$ Long-term moisture content (gravimetric)

$E_{v}=$ annual lake evaporation (inches

$P_{p}=$ annual precipitation (inches)

$f_{c m}^{p}=$ fraction of soil passing No. 200 sieve

$\gamma_{d}=d r y$ density (poof)

$G_{6}=$ specific gravity

$E_{v}=46$ inches (Call. No. $11-314-03-00$ )

$P_{p}=10.82$ inches (call. Ne. 11-250-04-03)
$f_{c m}=0.47$ (call$$
\gamma_{d}=102.5 \text { pdf (Call. No. } 11-321-01-00 \text { ) }
$$$$
G_{s}=2.7 \text { (" " ") }
$$

$$
\therefore \omega_{r}=9.4 \%
$$

DOE/AL/62350-197
REV. O, YER. 5

$-31-$

OO9D5CRD.DOC (SK) (WCI/L) 
RAECORET. FOR - SUMMARY OF INPUT

IKPUT FILEMAME: Srk56.dag

MEAOING: UMTRA - SLICKROCK, RADON GARRIER aKALYSIS, MAVERAGE" CONDITION

LAYERS:

INITIAL FLUX: $\quad .000$

AMBIENT RN: $\quad 1.500$

PIIMIZEO LATER: 4

SURFACE FLUX LIMIT: 20.000

PRECISION: $\quad .0010$

\begin{tabular}{|c|c|c|c|c|c|c|c|c|c|}
\hline $\begin{array}{l}\text { LAYER } \\
\text { NO. }\end{array}$ & $\begin{array}{l}\text { THICXNESS } \\
\text { on }\end{array}$ & $\begin{array}{l}\text { DIFFusion } \\
\text { OMZ-SEC }\end{array}$ & $\begin{array}{l}\text { Porosity } \\
\text { Fraction }\end{array}$ & $\begin{array}{l}R A-226 \\
P C I / G\end{array}$ & $\begin{array}{l}\text { EMANAT TNG } \\
\text { FRACTION }\end{array}$ & $\begin{array}{l}\text { BULX DENSITY } \\
\text { G/CMB }\end{array}$ & $\begin{array}{l}\text { SOURCE IERY } \\
\text { PCI/CH }- \text { SEC }\end{array}$ & $\begin{array}{l}\text { MOISTURE } \\
\mathrm{X} \text { DRY UT }\end{array}$ & $\begin{array}{l}\text { SPECIFIC } \\
\text { GRAYITY }\end{array}$ \\
\hline 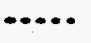 & $\cdots$ & •......... & $\ldots \ldots \ldots$ & $\ldots \ldots$ & $\cdots$ & & & & \\
\hline 6 & 61.0 & .01100 & .370 & .0 & .00 & 1.72 & .0000000 & 11.6000 & 2.737 \\
\hline 3 & 15.0 & .02300 & .392 & 35.0 & .31 & 1.64 & .0000954 & 6.0000 & 2.702 \\
\hline 2 & 1067.0 & .02900 & .659 & 135.0 & .19 & 1.46 & .0001706 & 4.3000 & 2.689 \\
\hline 1 & 762.0 & .01900 & .660 & 365.0 & .42 & 1.51 & .0010453 & 8.5000 & 2.702 \\
\hline
\end{tabular}

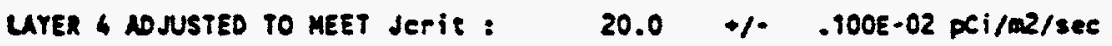

aARE SQURCE FLUX (JO) FROM LAYER I : 437.7 pCi/m2/see

\#\#: RESULTS OF RADON OIFFUSION MOOELING

\begin{tabular}{|c|c|c|}
\hline LAYER & $\begin{array}{c}\text { THICKNESS } \\
\text { (em) }\end{array}$ & $\begin{array}{c}\text { Exit flux } \\
(p i / m 2 / \sec )\end{array}$ \\
\hline 4 & 62. & $2.0018 E * 01$ \\
\hline 3 & 15. & $2.7774 E+01$ \\
\hline 2 & 1067. & $2.81825+01$ \\
\hline 1 & 762. & $2.2395 E+02$ \\
\hline
\end{tabular}

\section{CALCULATION - MECOMET/FOR}

ExIt cone. (pcilliter)

$9.0005 E \cdot 01$

$4.6663 E+04$

$5.6462 E+04$

$2.4328 E+05$
HIC

.6000

.8139

.8991

.7837
Ass conc. (pci/l)

n20 conc.

$.1500 E+01$

$.5709 E+05$ $.6280 E+05$ $.3104 E+06$ (pill)

$.3900 E+00$

$.1684 E+05$

$.1633 E+05$

$.8071 E+05$ 
COMMENT

Site: Slick Rock, Colorado Date: 28 July 1994

Document: Final Remedial Action Plan

Reviewer: U.S. Nuclear Regulatory Commission (NRC)

Comment: 19

DOE must commit to providing additional radon diffusion coefficient measurements on the UC offpile and subpile material for the final RAECOM analysis (radon flux estimation).

\section{RESPONSE}

Page: By: $\quad$ A. M. Banani (RAC)

Date: 9 August 1994

Additional radon diffusion coefficients and emanation fraction measurements will be obtained on UC subpile and offpile materials during construction. These data along with the actual thickness and radium concentrations of placed contaminated materials will be used to recalculate or more precisely define the radon barrier thickness in the final RAECOM analysis.

\section{Plans for Implementation}

Radon diffusion coefficient and emanation fraction measurements will be obtained during construction and incorporated into the final RAECOM analysis. 


\section{COMMENT}

Site: Slick Rock, Colorado

Date: 28 July 1994

Document: Final Remedial Action Plan

Reviewer: U.S. Nuclear Regulatory Commission (NRC)

Comment: $\underline{20}$

DOE must commit to using a measured or conservative (default) value for the UC subpile material radon emanation fraction in the final RAECOM analysis.

\section{RESPONSE}

Page: By:

See response to Comment No. 19.

Plans for Implementation

See response to Comment No. 19. 


\section{COMMENT}

Site: Slick Rock, Colorado

Date: 28 July 1994

Document: Final Remedial Action Plan

Reviewer: U.S. Nuclear Regulatory Commission (NRC)

Comment: $\underline{21}$

DOE must provide Ra-226 concentration data for the radon barrier soil.

\section{RESPONSE}

Page: By:

Since the background $\mathrm{Ra}-226$ values average $1.5 \mathrm{pCi} / \mathrm{g}$ and uranium mining has not occurred in the borrow area, this background value appears to be valid for the borrow area soils. Using $1.5 \mathrm{pCi} / \mathrm{g}$ in a RAECOM calculation with a reasonable emanation fraction for the cover and all other values as taken from Table 6.1 of the NRC RAP evaluation yields an acceptable flux.

\section{Plans for Implementation}

None. 


\section{COMMENT}

Site: Slick Rock, Colorado

Date: 28 July 1994

Document: Final Remedial Action Plan

Reviewer: U.S. Nuclear Regulatory Commission (NRC)

Comment: 22

DOE must revise the specifications or the Remedial Action Selection Report (Section 5) concerning the placement compaction of the radon barrier soil to be consistent.

\section{RESPONSE}

Page:

By:

A. M. Banani (RAC)

Date: 9 August 1994

Compaction requirements for radon barrier material calls for 95 percent of Standard Proctor maximum dry density which is in agreement with the Remedial Action Selection Report. Please refer to Subcontract Document, Final Design for Construction.

\section{Plans for Implementation}

None required. 


\section{COMMENT}

Site: Slick Rock, Colorado Date: 28 July 1994

Document: Final Remedial Action Plan

Reviewer: U.S. Nuclear Regulatory Commission (NRC)

Comment: $\underline{23}$

DOE must provide additional characterization data for Th-230 in the areas of boreholes 214 and 226 , and at grid point $58550 \mathrm{~N} 63400$ or plan verification sampling for Th-230 in these areas.

\section{RESPONSE}

Page: _ By: M. J. Brennan (TAC) Date: 9 August 1994

In those areas where elevated Th-230 values have been found, the final verification will include Th-230 analyses. Final cleanup in such areas will be conducted in accordance with the UMTRA Project thorium protocol.

\section{Plans for Implementation}

Section 6.5.3 of the Remedial Action Selection Report was revised to include the cleanup and verification of Th-230 in accordance with the NRC-approved generic protocol for Th-230. 


\section{COMMENT}

Site: Slick Rock, Colorado

Date: 28 July 1994

Document: Final Remedial Action Plan

Reviewer: U.S. Nuclear Regulatory Commission (NRC)

Comment: 24

DOE must provide additional characterization of this property for the supplemental standards application.

\section{RESPONSE}

Page:

By:

M. J. Brennan (TAC)

Date: 9 August 1994

The TAC does not believe that additional information is needed in the RAP. The DOE does, however, concur that additional information will be needed for the formal Application for Supplemental Standards.

\section{Plans for Implementation}

The RAC currently is obtaining the requested information which will be transmitted to NRC under separate cover. 


\section{COMMENT}

Site: Slick Rock, Colorado

Document: Final Remedial Action Plan

Reviewer: Colorado Department of Public Health and Environment (CDPHE)
Date: 27 April 1994 and

7 November 1994

Comment: 1: Appendix C to Attachment 3, Calculation No. SRK-11-93-12-06-00

Our comment may suggest that the excavation of this disposal cell to a depth greater than that assumed by the seepage calculation. What is the break even point between additional excavation and the construction of a clay liner as proposed in the original design? $(4 / 27 / 94)$

The DOE's (initial draft) response to CDPHE's Comment No. 1 of $4 / 27 / 94$, stated that "... blasting is required to excavate into the unweathered zones of the Burro Canyon Formation." In addition, the response said, "The current excavation depth extends to, or just below, the Dakota-Burro Canyon interface..." However, a NW to SE section of the Burro Canyon site provided to CDPHE by the DOE in November 1994 (attached), indicated an excavation depth of 23-28 feet below this interface. CDPHE went on to comment, "Does DOE expect this depth can be reached by ripping or will blasting be required? If the use of explosives is required, CDPHE believes a careful analysis of the costs of drilling and blasting to the currently designed depth must be weighted against the cost of a clay liner, underdrain system or other mean of preventing migration of leachate from the cell. CDPHE also wishes to minimize the overall cost of remedial action while reducing to a minimum the overall the disturbance to surrounding areas. How will DOE reduce the height and footprint of the permanent spoil pile by excavating a larger amount of material from the cell? Please provide CDPHE with a cost-benefit analysis of a cell design utilizing a liner or underdrain to restrict the migration of leachate into the Dakota Sandstone stringers versus the current design."

\section{RESPONSE}

Page

By:

A. Banani (RAC): J. Crain, M. B. Leaf (TAC)

Date: 2 June 1995

In the draft RAP, the cell excavation was proposed as about 30 feet $(\mathrm{ft})(9$ meters $[\mathrm{m}]$ throughout, to elevation $\mathbf{5 8 3 5}$ at the deep end of the cell. The design included the 8-ft (2-m)-thick clay liner and the cell sideslopes were about 1 to 2.5. The depth below the lower Dakota Sandstone and into the Burro Canyon Formation in this shallower cell formerly averaged about 3 to $19 \mathrm{ft}(1$ to $6 \mathrm{~m})$. This area is considered part of the "weathered" zone. 
The UNSAT-2 model analysis in the seepage report (Calculation No. SRK-11-93-1206-00) prepared in the fall of 1993 considered the shallower draft RAP design and recommended a minimal depth of excavation in the impermeable mudstone/claystone to create a sidewall liner height of $5 \mathrm{ft}(1.5 \mathrm{~m})$ or greater. To add a reasonable factor of safety to account for greater than assumed placement moisture content of the RRM and for lower assumed cell bottom permeability, the excavation was recommended at preferably 7 to $8 \mathrm{ft}(2$ to $2.5 \mathrm{~m})$. Also, it determined a permissible range of saturated hydraulic conductivities for the radon/infiltration barrier as $1.0 \mathrm{E}-6$ to $1.7 \mathrm{E}-7$, and an average value of 5.0E-7. The cell bottom flux for the Burro Canyon disposal cell of $3.0 \mathrm{E}-6$ is thought to be most representative of the drainage rate that will occur at the tailings/foundation interface, based on existing packer test information.

The TAC seepage report recommended deleting the clay liner and steepening the cell sidewall. The design in the March 1994 preliminary final RAP deleted the clay liner and steepened the sideslopes to 1 to 1 . The total excavation depth in the revised design ranged from about $30 \mathrm{ft}(9 \mathrm{~m})$ at the shallow end to about 45 to $50 \mathrm{ft}(14$ to $15 \mathrm{~m}$ ) at the deep end of the cell. It resulted in a proposed cell floor ranging from about $10 \mathrm{ft}(3 \mathrm{~m})$ (core \#531) to 20 to $36 \mathrm{ft}(6$ to $11 \mathrm{~m}$ ) (cores \#606 and 607) below the Dakota Sandstone and into the Burro Canyon Formation at the deep end of the cell, and 2 to $13 \mathrm{ft}(1$ to $4 \mathrm{~m})$ at the shallow end of the cell. With the Remedial Action Contractor (RAC) commitment to use a field geologist to direct the excavation to a minimum of $7 \mathrm{ft}(2 \mathrm{~m})$ below the Dakota/Burro Canyon interface, this will create a minimum $7 \mathrm{ft}(2 \mathrm{~m})$ (core \#531 area) sidewall liner throughout the cell, and upwards of a 20 to $39 \mathrm{ft}(6$ to $12 \mathrm{~m}$ ) "natural sidewall liner" at the deep end of the cell. This excavation is still considered to be mostly in the "weathered" zone, with perhaps some portions of the extreme southern or deepest end of the cell venturing into the "unweathered" Burro Canyon Formation at depths greater than 45 to $50 \mathrm{ft}$ (11 to $15 \mathrm{~m}$ ).

The subsequent TAC water balance calculation (Calculation No. SRK-09-94-1201-00), which supersedes the seepage report (Calculation No. SRK-11-93-12-06-00), addressed the deeper preliminary final RAP cell design, and determined again that lateral drainage through the Dakota Sandstone was not an issue.

The disposal cell will extend through the Dakota Sandstone/Burro Canyon Formation interface and through portions of the Burro Canyon Formation that core logs indicate is fractured and weathered. Portions of the deepest part of the cell may be excavated into more unweathered portions of the Burro Canyon Formation. Most of the Dakota Sandstone and Burro Canyon Formation material is considered to be rippable by large bulldozers such as a DC-10. Some portions of the 2- to 5 -ft (1- to 2-m)-thick Dakota Sandstone lenses exposed in the cell excavation and perhaps some limited portions of the Burro Canyon Formation in the deepest portions of the cell may require limited blasting. 
Finally, eliminating the clay liner will reduce the overall cost of the remedial action and reduce the disturbance to surrounding areas by eliminating the need for a separate borrow source for the fine-grained soil required to construct the liner. Thus, the TAC did not evaluate other design features for controlling lateral seepage. In addition, the DOE is aware that excavating deeper in the Burro Canyon Formation will greatly increase the volume of unusable (spoil) material. For aesthetics, as well as to reduce the area permanently withdrawn from public use, the DOE wants to minimize both the footprint and height of the permanent spoil pile.

The disposal cell at the Burro Canyon disposal site is on a small mesa and will contain approximately 620,000 cubic yards $\left(\mathrm{yd}^{3}\right)$ of contaminated material.

The size of site boundary is restricted by the following:

- The area of archaeological significance to the east.

- The crest of the mesa to the north and west.

- The crest of the mesa to the south.

- The potential for gully development in the Burro Canyon Formation to the south.

To avoid adverse effects of surface water drainage and to ensure the long-term stability of the disposal cell, the footprint of the cell is limited to 12 acres (ac) (5 hectares [ha]).

Due to these space limitations, to ensure some contingency, and to minimize the height of the disposal cell, the excavation at the site was designed to hold approximately $500,000 \mathrm{yd}^{3}$ of material. Approximately $150,000 \mathrm{yd}^{3}$ of excavated materials from the disposal cell foundation will be used for final site grading and cover construction. The remaining $350,000 \mathrm{yd}^{3}$ will be placed in a permanent spoil pile. The spoil pile will be graded and seeded to blend with the surrounding terrain.

Using suitable portions of the excavation materials for the radon barrier eliminates the need for using the Disappointment Valley borrow source and for placing an extended overlay on the state highway between it and the disposal site.

\section{Plans for Implementation}

An on-site RAC geologist will evaluate conditions in the cell excavation to limit the amount of blasting needed. In addition, the areal extent of blasting will be limited for cost, for safety and control reasons, and to limit adverse cracking of the rock of the cell floor and walls. The bottom and sideslopes will be inspected before fill emplacement, as agreed with the Colorado Department of Public Health and Environment (CDPHE).

The RAP will be reviewed and references to depth of excavation and the need for blasting and ripping will be made consistent throughout. 


\section{COMMENT}

Site: Slick Rock, Colorado

Date: 27 April 1994

Document: Final Remedial Action Plan

Reviewer: Colorado Department of Public Health and

Environment (CDPHE)

\section{Comment: 2; Appendix C to Attachment 3, Calculation No. SRK-11-93-12-06-00}

There does not appear to be any data related to a study of the "rip ability" of the claystones into which the disposal cell will be excavated. Increased costs may be expected if the claystones cannot be ripped to the proper depth and must be excavated by other means. Can the "rip ability" of this material be inferred from any existing data? If not, thought should be given to acquiring data adequate to demonstrate the physical characteristics of this material.

\section{RESPONSE}

Response: Page _ By: J. Crain, M. B. Leaf (TAC) Date: 2 June 1995

Numerous field investigations were conducted at the Burro Canyon disposal site by the TAC and RAC - the latest completed in November 1993. Although sonic tests (ASTM D2845-90) of core samples were not performed to determine the engineering parameters of the rock layers, site geologists and engineers concluded that most of the Dakota Sandstone, regardless of the lithology, and the weathered mudstone and claystone of the Burro Canyon Formation can be ripped with a bulldozer. The previous judgment by TAC and RAC personnel is based on field observations, including the following: 1) a small backhoe can penetrate the mudstone and shale, and 2 ) most of the siltstone is a facies variant of the shale and mudstone and therefore rippable.

Estimates of the volume of rippable and nonrippable materials are presented in MK-ES Calculation No. 11-333-02-00. To estimate the quantities of ripple and nonrippable material, the RAC assumed conservatively that none of the sandstone is rippable. However, sections of the sandstone layers, especially lenses that are 3 to $4 \mathrm{ft}$ (approximately $1 \mathrm{~m}$ ) thick or less, can be ripped when a large enough area is cleared to allow access by a large bulldozer. This previous assertion is based on the following field observations: 1) a small backhoe can penetrate the thinner lenses of the sandstone layers, and 2) at several mining claims downdip of the disposal site, small backhoes and bulldozers were used to rip the unweathered sandstone layers. As stated in the response to CDPHE Comment No. 1, some localized areas of both formations may not be rippable and may need limited blasting to complete the cell excavation. 


\section{Plans for Implementation}

Comment acknowledged. Based on the currently available information, the DOE is reasonably certain which materials at the disposal site can be ripped and which materials cannot. Thus, further geotechnical characterization of the disposal site is unnecessary. As stated in the response to CDPHE Comment No. 1, an on-site geologist will determine the need for blasting and limit it to just these areas determined to be unrippable. 


\section{COMMENT}

Site: Slick Rock, Colorado

Document: Final Remedial Action Plan

Reviewer: Colorado Department of Public Health and Environment (CDPHE)
Date: 27 April 1994 and

7 November 1994

\section{Comment: 3: Appendix C to Attachment 3, Calculation No. SRK-11-93-12-06-00}

The range of permeabilities for the Burro Canyon Formation is stated on page 10 as $1.8 \times 1.0 \times 10^{-4}$ to $1.0 \times 10^{-8} \mathrm{~cm} / \mathrm{s}$. Lab permeabilities as low as $4.4 \times 10^{-11}$ are reported. If these permeabilities are representative of the Burro Canyon Formation, a model employing a lower permeability, perhaps $1.0 \times 10^{-8}$, should be analyzed. We assume the model will be sensitive to this parameter and conclude the case used to predict 1.5 meters of saturation may not be representative of conditions at the site.

\section{RESPONSE}

Response: Page By: J. Crain, M. B. Leaf (TAC): Date: 1 April 1995 A. Banani (RAC)

The DOE cannot support CDPHE's request for a more conservative cell floor permeability of $1.0 E-8 \mathrm{~cm} / \mathrm{s}$. While the DOE has acknowledged that the revised preliminary final RAP design has resulted in the bottom of the cell extending at ranges of 10 to $36 \mathrm{ft}(3$ to $11 \mathrm{~m})$ into the Burro Canyon Formation, core data collected to date do not support the CDPHE's assertion that the entire cell is emplaced in "unweathered" Burro Canyon Formation material. Packer tests conducted on core from \#531 indicate values of $2.2 \mathrm{E}-6$ to $2.5 \mathrm{E}-6 \mathrm{~cm} / \mathrm{s}$. The seepage report determined that a conservative value of $3.0 \mathrm{E}-06 \mathrm{~cm} / \mathrm{s}$ is representative for analysis of the shallower design, and data do not support that the strata become much more impermeable in the design for a cell about $15 \mathrm{ft}(5 \mathrm{~m})$ deeper.

The seepage report data presenting very low values were taken from laboratory tests of unweathered rock samples obtained in most cases well below this level. The packer test result of $1.0 E-8 \mathrm{~cm} / \mathrm{s}$ was determined from a test on a zone also located considerably below the planned excavation depth. The seepage report's higher values in the $1.0 \mathrm{E}-4$ to $1.0 \mathrm{E}-6 \mathrm{~cm} / \mathrm{s}$ range were determined by packer tests of the fine-grained material at the interface of the Dakota Sandstone and Burro Canyon Formation. The bottom of the cell presented in the draft RAP design was closer to this interface, and the more conservative use of the $1.0 \mathrm{E}-6 \mathrm{~cm} / \mathrm{s}$ value as the model input parameter was appropriate. The simulated results were suitably conservative for disposal cell design purposes. The preliminary final RAP design excavation is somewhat deeper, but the parameter selected is still representative of actual field 
conditions and the result is still suitably conservative for disposal cell design purposes.

The seepage report also determined the permissible range of saturated hydraulic conductivities for the radon/infiltration barrier is $1.0 \mathrm{E}-6$ to $1.7 \mathrm{E}-7 \mathrm{~cm} / \mathrm{s}$; an average value of $5.0 \mathrm{E}-7 \mathrm{~cm} / \mathrm{s}$ was determined appropriate for the cover material. In light of the DOE's accepted cover and cell floor flux values, the recently tested Burro Canyon excavation material results indicate that the material is still suitable from an infiltration perspective and will resolve long-term "bathtub" effects. Careful attention to selection and compaction of the material in the field will guarantee its effectiveness as a cover material.

\section{Plans for Implementation}

None. 


\section{COMMENT}

Site: Slick Rock, Colorado

Document: Final Remedial Action Plan

Date: 27 April 1994

Reviewer: Colorado Department of Public Health and Environment (CDPHE)

Comment: 4: Appendix C to Attachment 3, Calculation No. SRK-11-93-12-06-00

The seepage analysis describes a placement sequence not specified in the subcontract documents. If a more moist material is placed lower in the cell, the depth of the saturated zone may increase. To assure that modeling efforts account for this possibility, other placement sequences should be analyzed. Alternatively, the modeled sequence should be stipulated in the specifications.

\section{RESPONSE}

Response: Page

By: J. Crain (TAC)

Date: 1 April 1995

A contaminated material placement sequence is specified in SubContract Documents, Section 02200, Rev. B - Earthwork, Item 3.5, B., 6 (a-i), page 24. The placement sequence described on page 10 of the seepage report and depicted in Figure A.1 of the appendix is identical to the placement sequence of contaminated material specified in Subcontract Documents.

The three specified contaminated material layers contain different material types; for example, the NC tailings are sand, but the NC-contaminated subpile soil is mostly silty-clayey sand with gravel. Regardless of whether the two NC materials are mixed during excavation, hauling, and placement, or whether the materials remain segregated, the assumed volume of drainable water in the materials is a constant and the computer-simulated heights and durations of the saturated zone at the foundation of the disposal cell should not change significantly.

\section{Plans for Implementation}

None. 


\section{UMTRA DOCUMENT REVIEW FORM}

\section{COMMENT}

Site: Slick Rock, Colorado

Document: Final Remedial Action Plan

Date: 27 April 1994

Reviewer: Colorado Department of Public Health and Environment (CDPHE)

Comment: 5; Appendix C to Attachment 3, Calculation No. SRK-11-93-12-06-00

The conclusions of the seepage analysis depend on the assumption that additional water will not be required for compaction. The case assuming only in-situ moisture content concludes that 1.5 meters of saturation will result. However, addition of water may be necessary for dust control as experienced at other Colorado UMTRA sites. In our opinion, it would be a violation of ALARA principles if the project were forced to accept increased exposure to the workers and public in order to avoid violating the logic for eliminating the clay liner. We are not convinced the "in-situ" case is representative of the conditions that will occur during construction. Worker and public safety must not be compromised in order to minimize the amount of saturation that may occur. Our preference is to construct the cell to such a depth that water applied for dust control can be accommodated without compromising the integrity of the cell.

\section{RESPONSE}

Response: Page

By: A. M. Banani (RAC)

Date: 31 March 1995

See Section 00800, Special Conditions, Article SC-3, and Section 01560, Temporary Controls, Article 1.4 of the Subcontract Document, Final Design for Construction (June 1994), for dust control measures during construction of the disposal cell (attached). These restrictions will be implemented and monitored by the RAC site manager, who is aware of the need to minimize the use of construction water. The subcontractor must also be informed of these restrictions. In addition, four stand pipes will be installed in the cell and will be used to monitor any water buildup during construction. If necessary, the stand pipes will be used to remove any water that accumulates before the radon/infiltration barrier is emplaced.

\section{Plans for Implementation}

None. A copy of the specifications were sent to CDPHE on 19 April 1994. 


\section{COMMENT}

Site: Slick Rock, Colorado Date: 27 April 1994

Document: Final Remedial Action Plan

Reviewer: Colorado Department of Public Health and Environment (CDPHE)

Comment: 6; Appendix C to Attachment 3, Calculation No. SRK-11-93-12-06-00

The results of the model appear to be very sensitive to the initial moisture content of the material. $\mathrm{CDH}$ would like to review the initial assumptions in more detail. The calculation presents aggregate values for the various materials but the documentation for these aggregate values is absent. Please provide more detailed documentation describing how the initial moisture content values used in the model were derived.

\section{RESPONSE}

Response: Page

By: J. Crain (TAC)

Date: 1 May 1995

Aggregate values of moisture content for the different classes of contaminated material are presented in MK-ES Calculation Nos. 11-250-04-03, Embankment Material Properties, and 11-321-01-00, Radon Barrier Design-RAECOM Input Data. The field notes (sheets) and laboratory data sheets are found in Information for Bidders, Volume I. The TAC also used qualitative information to bolster conclusions and design recommendations presented in the seepage report; the following qualitative details are relevant:

- The DOE placed suction lysimeters in the UC tailings pile in 1987, 1988, and 1991; however, pore fluid could not be extracted during the sampling efforts. The site hydrologists assumed that the lysimeters were installed and sampled correctly, and concluded that the moisture content of the in situ UC tailings was very low.

- Both the TAC and RAC performed numerous sieve analyses of the NC and UC tailings. In addition, Merritt (1971) and other investigators reported that the tailings were discharged from the UC mill and the older NC mill into segregated, fine-grained and coarse-grained piles. The fine-grained tailings from both the UC and NC sites subsequently were excavated and transported to the New Rifle mill. Thus, there is little uncertainty about the physical characteristics of UC and NC tailings. The tailings at both sites are poorly graded sand and the hydraulic properties of uniform sand are well documented. The very low in situ moisture 
content and high conductivity of the UC and NC tailings are consistent with the established properties of a sandy material.

- The model results are also sensitive to parameters other than the assumed initial moisture content. For example, the predicted depth and persistence of the saturated zone are sensitive to the saturated conductivity of the radon barrier. However, both the conductivity of the radon barrier and the placement moisture content of a contaminated material layer are reasonably assumed to be controllable through specified construction techniques and practices.

Additionally, one-dimensional (profile) flow model results are conservative, because the predicted depths of a saturated zone are exaggerated by the dimensional constraint of flow occurring only in two directions.

\section{Plans for Implementation}

No action required. 


\section{COMMENT}

Site: Slick Rock, Colorado

Date: 27 April 1994

Document: Final Remedial Action Plan

Reviewer: Colorado Department of Public Health and Environment (CDPHE)

Comment: $\underline{Z}$

1. RASR, page ES-1, Final Paragraph: "The mudstone/claystone will provide a natural impermeable barrier from the base of the pit to approximately 1.5 meters up to the side wall to form a continuous saucer-shaped bottom and side liner."

2. RASR, page 5-27, 4th bullet: "The disposal cell design calls for excavating approximately 2.0 to 2.5 meters into the claystones and mudstone at the base of the Dakota Sandstone Formation and Burro Canyon upper mudstone unit."

3. Attachment 4, Page 2-6, First Paragraph: "Based on the UNSAT2 model results, the maximum height of the saturated zone would be less than $1.5 \mathrm{~m}$. However, the disposal cell has been designed to take advantage of the low-permeability foundation materials. Excavated mudstone and claystone will provide an impermeable layer for a "liner effect" from the base of the pit to approximately 2.0 to $2.5 \mathrm{~m}$ up the sidewall. Thus, the design is conservative in that the height of the "sidewall liner" (i.e. naturally occurring low permeability mudstone and claystone) is approximately $1 \mathrm{~m}$ above the predicted height of the saturated zone $(1.5 \mathrm{~m}) . "$

The RAP text does not seem to agree with the design drawings provided us by DOE which indicate a depth of excavation considerably greater than 1.5 to 2.5 meters into the Burro Canyon Formation. Please clarify this apparent discrepancy.

As a side note, RASR, Table 1.2, Page 1-13, listed under "Remarks" for "Geotechnical": Based on a simplified approach, there is potential for cover cracking at the north edge of the pile." All other references to cover cracking (i.e., Section 3.3.3, Page 3-7) claim that no cracking is expected. This contradiction should be resolved.

\section{RESPONSE}

Response: Page

By: A. Banani (RAC): J. Crain, M. B. Leaf (TAC)

Date: 1 May 1995

See response to Comment No. 1. 
The RAP depth of excavation/sidewall liner inconsistencies noted in CDPHE Comment No. 7 resulted from recommendation language from the seepage report being inconsistent with the results of the preliminary final RAP design change of removing the liner and steepening the cell sideslopes. The design change resulted in an overall deeper excavation: 20 to $39 \mathrm{ft}(6$ to $11 \mathrm{~m})$, though as shallow as 5 to $8 \mathrm{ft}(2$ to $25 \mathrm{~m})$ in the core \#531 area, with a minimum of a $7 \mathrm{ft}(2 \mathrm{~m})$ of natural liner. However, the "natural sidewall liner" formed by the Burro Canyon Formation material is mostly "higher" than recommended in the seepage report, ensuring no lateral seepage through the Dakota Sandstone.

\section{Plans for Implementation}

All language referring to the excavation depth in relation to the formations of discussion and the effective creation of a "natural sidewall liner" will be checked and made consistent, as described above.

In addition, the language referring to "cover cracking" will be removed based on the revised cover cracking calculation. 


\section{COMMENT}

Site: Slick Rock, Colorado

Date: 27 April 1994

Document: Final Remedial Action Plan

Reviewer: Colorado Department of Public Health and Environment (CDPHE)

\section{Comment: 8; Appendix C to Attachment 3, Figure 3.1, Page 3-3}

Figure 3.1 has been revised to show locations of both privately-owned wells and lysimeters. In addition, wells identified as \#684 and \#685 north of the UC site have been added. These wells are labeled privately owned but are noted as on-site DOE monitor wells in Table 3.2. Water level measurements for these wells are included in Table 3.3. However, water quality data for these wells are not provided even though the data are mentioned in the text on page 3-37, Section 3.1.9. Please clarify ownership of wells \#684 and \#685 and provide the water quality data.

\section{RESPONSE}

Response: Page

By: $\quad$ K. Lambert (TAC)

Date: 19 April 1995

Wells \#684 and \#685 are downgradient alluvial DOE monitor wells. Requested water quality data were transmitted to CDPHE in April 1995. Figure 3.1 was revised to show these wells as alluvial DOE monitor wells. Table 3.2 (Appendix to Attachment 3) was revised to indicate these wells are downgradient (north) of the UC site. A new Table 3.54 was added to the Appendix A of Attachment 3, showing the water quality data for these wells.

\section{Plans for Implementation}

Text was revised as requested. 


\section{COMMENT}

Site: Slick Rock, Colorado

Date: 7 April 1994

Document: Final Remedial Action Plan

Reviewer: A.M. Banani (RAC)

Comment: 1; Remedial Action Selection Report, Introduction

Page 1-4, Section 1.2.3, Contaminated Materials

Revise contaminated material quantities in Table 1.1 as follows:

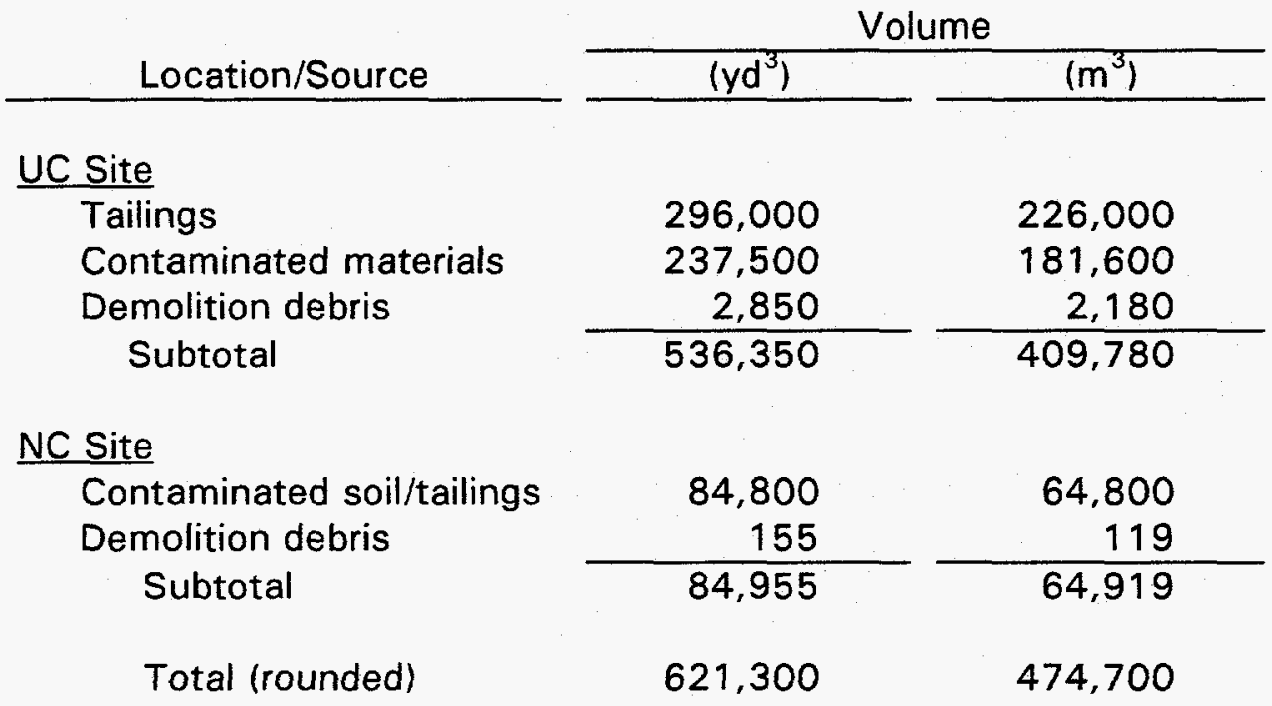

\section{RESPONSE}

Response: Page

By: J. Crain (TAC)

Date: 1 June 1994

Comment acknowledged.

Plans for Implementation

The material quantities in the table and text were revised as requested. 


\section{COMMENT}

Site: Slick Rock, Colorado

Date: 7 April 1994

Document: Final Remedial Action Plan

Reviewer: A. M. Banani (RAC)

Comment: 2; Remedial Action Selection Report, Introduction

Page 1-8, Figure 1.5, Disposal Cell for the Slick Rock Tailings

The bar scale showing the scale in meters is not correct. Change " 90 " to " 30 " and "180" to "60."

\section{RESPONSE}

Response: Page

By: J. Crain (TAC)

Date: 1 June 1994

Comment acknowledged.

Plans for Implementation

The bar scale was corrected as requested. 


\section{COMMENT}

Site: Slick Rock, Colorado Date: 7 April 1994

Document: Final Remedial Action Plan

Reviewer: A. M. Banani (RAC)

Comment: 3; Remedial Action Selection Report, Introduction

Page 1-9, Fig. 1.6, Detail 2

Delete the first dashed line from top.

\section{RESPONSE}

Response: Page

By: J. Crain (TAC)

Date: 1 June 1994

Comment acknowledged.

Plans for Implementation

The first dashed line from the top was deleted from the figure as requested. 


\section{COMMENT}

Site: Slick Rock, Colorado

Date: 7 April 1994

Document: Final Remedial Action Plan

Reviewer: A. M. Banani (RAC)

Comment: 4; Remedial Action Selection Report, Geotechnical Engineering

Page 3-2, Borrow areas: Suggested adding "Currently, laboratory testing is being conducted to determine if fine-grained material from excavations at the Burro Canyon disposal site is suitable as radon barrier material."

\section{RESPONSE}

Response: Page _ By: J.Crain (TAC) Date: 1 June 1994

Comment acknowledged.

\section{Plans for Implementation}

The text was revised to reflect the results of the laboratory testing, which indicated that the Burro Canyon material is suitable for use as the radon barrier source. 


\section{COMMENT}

Site: Slick Rock, Colorado

Date: 7 April 1994

Document: Final Remedial Action Plan

Reviewer: A. M. Banani (RAC)

Comment: 5: Remedial Action Selection Report, Geotechnical Engineering

Page 3-9, Section 3.4.1, 7th bullet, 2 nd line: Suggest changing "... at or near the optimum moisture content, ..." to "at, or above optimum moisture content, ...."

\section{RESPONSE}

Response: Page

By: J. Crain (TAC)

Date: 1 June 1994

Because of CDPHE concerns about the depth of the saturated zone that may form at the bottom of the excavation, the TAC recommends that the contaminated material be placed at or below optimum water content. Given the material types found at the sites (i.e., sand tailings and sandy-gravely soils), specified compaction densities probably can be achieved at less than optimum moisture contents.

Plans for Implementation

None. 


\section{COMMENT}

Site: Slick Rock, Colorado

Date: 7 April 1994

Document: Final Remedial Action Plan

Reviewer: A. M. Banani (RAC)

Comment: 6; Remedial Action Selection Report, Geotechnical Engineering

Page 3-13, Schedule

1. After first sentence, add: "major office trailers and access control will be installed at the BC site beginning October 1994."

2. Add the construction schedule (attached).

\section{RESPONSE}

Response: Page

By: J. Crain (TAC)

Date: 1 June 1994

Comments acknowledged. However, subsequent delays in accessing the Burro Canyon disposal site resulted in a change in office location to the UC site. Installation of these facilities commenced in late 1994. Access control facilities at the BC site commenced in spring 1995.

\section{Plans for Implementation}

The requested text revision is not necessary and was not made. The construction schedule was included in the RAP as requested. 


\section{COMMENT}

Site: Slick Rock, Colorado

Date: 7 April 1994

Document: Final Remedial Action Plan

Reviewer: A. M. Banani (RAC)

Comment: 7; Remedial Action Selection Report, Radon Attenuation and Site Cleanup

Page 6-2, 2nd Paragraph

There are no plans for additional field investigations and laboratory testing for Disappointment Valley radon barrier material prior to construction. However, currently laboratory tests are being performed on in-situ fine grained materials from $B C$ site to find out if the material is suitable to be used for radon barrier.

Revise the paragraph accordingly.

\section{RESPONSE}

Response: Page

By: J. Crain (TAC)

Date: 1 June 1994

The Burro Canyon material was subsequently determined to be acceptable for use as a radon barrier source, so no further testing of the Disappointment Valley material was conducted.

\section{Plans for Implementation}

The text was revised to reflect the selection of the Burro Canyon disposal cell excavation material as the radon barrier borrow source. 


\section{COMMENT}

Site: Slick Rock, Colorado Date: 7 April 1994

Document: Final Remedial Action Plan

Reviewer: A. M. Banani (RAC)

Comment: 8 ; Remedial Action Selection Report, Radon Attenuation and Site Cleanup

Page 6-2, Section 6.3.2, Radon Diffusion

1. 6th Line: Suggest revising "....Were made, each at a different moisture content within the moisture content range. "to "... were made, each at a different moisture content, above and below the long-term moisture content estimates."

2. 10th Line: Diffusion coefficient of $1.1 \mathrm{E}-02 \mathrm{~cm}^{2}$ per second does not correspond to moisture saturation of 54 percent. This diffusion coefficient is the average of the diffusion coefficients of tested samples at their estimated long-term moisture content.

Revise the paragraph accordingly.

\section{RESPONSE}

Response: Page

By: J. Crain (TAC)

Date: 1 June 1994

Comment acknowledged.

Plans for Implementation

The text was revised as requested. 
COMMENT

Site: Slick Rock, Colorado

Date: 7 April 1994

Document: Final Remedial Action Plan

Reviewer: A. M. Banani (RAC)

Comment: 9; Remedial Action Selection Report, Radon Attenuation and Site Cleanup

Page 6-3, Section 6.3.4, Dry Densities and Porosities

2nd Paragraph: The first sentence is not clear. Number of samples mentioned is not correct. Refer to Radon Barrier Calculations and revise the paragraph accordingly.

\section{RESPONSE}

Response: Page

By: M. Brennan (TAC)

Date: 31 August 1995

Comment acknowledged.

Plans for Implementation

The text was revised as requested. 


\section{COMMENT}

Site: Slick Rock, Colorado

Date: 7 April 1994

Document: Final Remedial Action Plan

Reviewer: A. M. Banani (RAC)

Comment: 10; Remedial Action Selection Report, Geotechnical Engineering

Page 3-9, Section 3.4.1, Construction Methods and Features, 3rd, 6th, and 7th bullets: Suggest changing "(ASTM D698) (ASTM, 1991)" to (ASTM D698-90)".

\section{RESPONSE}

Response: Page

By: J. Crain (TAC)

Date: 1 June 1993

Comment acknowledged.

Plans for Implementation

The text was revised as requested. 


\section{COMMENT}

Site: Slick Rock, Colorado Date: 7 April 1994

Document: Final Remedial Action Plan

Reviewer: A.M. Banani (RAC)

Comment: 11; Remedial Action Selection Report, Geotechnical Engineering

Page 3-10, Section 3.4.3, 3rd Paragraph

3rd Line: Suggest changing "...contaminated runoff at the UC site to the retention basin for...." to "...contaminated runoff at the UC and BC sites to the retention basins for..."

\section{RESPONSE}

Response: Page

By: J. Crain (TAC)

Date: 1 June 1994

Comment acknowledged.

Plans for Implementation

The text was revised as requested. 


\section{COMMENT}

Site: Slick Rock, Colorado Date: 7 April 1994

Document: Final Remedial Action Plan

Reviewer: A. M. Banani (RAC)

Comment: 12; Remedial Action Selection Report, Geotechnical Engineering

Page 3-10, Section 3.4.3

1. 4th Paragraph, 4th Sentence: Suggest changing "in conjunction with the volume in the basin due to the average ..." to "... in conjunction with the maximum accumulated runoff volume in the basin due to the average..."

2. 5th Paragraph, 3rd Sentence: Suggest changing "....and the water surface." to ".... and the maximum water surface."

\section{RESPONSE}

Response: Page

By: J. Crain (TAC)

Date: 2 June 1994

The text was modified previously based on comments by Fang Wu and Josanthe Randeni.

\section{Plans for Implementation}

None. 


\section{COMMENT}

Site: Slick Rock, Colorado

Date: 7 April 1994

Document: Final Remedial Action Plan

Reviewer: A. M. Banani (RAC)

Comment: 13; Remedial Action Selection Report

Page 5-6, Figure 5.3, and Page 5-7, Figure 5.4

Suggest adding corehole and test pit locations and numbers from 1993 field investigations to these figures (see Subcontract Drawing No. SRK-DS-10-0338).

\section{RESPONSE}

Response: Page

By: J. Crain (TAC)

Date: 10 June 1994

The main purpose is to show the location of ground water monitor wells. For clarity, the locations of a few test pits and boreholes were added to Figure 5.3. No new coreholes (1993) are located on cross section A-A'.

Plans for Implementation

None required. 


\section{COMMENT}

Site: Slick Rock, Colorado

Date: 7 April 1994

Document: Final Remedial Action Plan

Reviewer: A. M. Banani (RAC)

Comment: 14: Remedial Action Selection Report, Introduction

Page 1-10, Section 1.2.4, Remedial Action

1. 4th Line from top: "Perimeter" is not shown in Figure 1.5.

2. 2nd paragraph, 6th sentence: My understanding is that the "buffer area" is the area covered from the edge of the tailings in the disposal cell to the edge of the mesa which shall be no less than $100 \mathrm{ft}$. If this is correct, change " 31 ac $(13$ ha)" to "6 ac (2.5 ha)" and "43 ac (17 ha)" to "18 ac (7.3 ha)". If not, please explain what you mean by "buffer area".

\section{RESPONSE}

Response: Page By: J. Crain (TAC) Date: 13 June 1994

The buffer area is defined as the difference between the area occupied by the disposal cell and the area permanently withdrawn from public use.

\section{Plans for Implementation}

The phrase "nor will it extend outside...." was deleted in response to the first comment. No revision was made in response to the second comment. 


\section{COMMENT}

Site: Slick Rock, Colorado Date: 7 April 1994

Document: Final Remedial Action Plan

Reviewer: A. M. Banani (RAC)

Comment: 15: Remedial Action Selection Report, Surface Water Hydrology and Erosion Protection

Page 4-5, Section 4.4.3 Toe and Sides of the Embankment

3rd Line: Change "...a 1-ft-(0.3-m)-thick sand/gravel bedding layer..." to "...a 6-inch(150-mm)-thick sand/gravel bedding layer..."

\section{RESPONSE}

Response: Page

By: J. Crain (TAC)

Date: 13 June 1994

Comment acknowledged.

Plans for Implementation

The text was revised as requested. 


\section{COMMENT}

Site: Slick Rock, Colorado

Document: Final Remedial Action Plan

Reviewer: A. M. Banani (RAC)

Comment: 16; Attachment 4, Water Resources Protection Strategy, Design Considerations

Page 2-2, Section 2.1.3., Subsurface Drainage

2nd Paragraph, 5th line from bottom: Disposal cell is founded on Burro Canyon Formation below the sandstone strata of Dakota formation. Delete word

"foundation" in "...Dakota Sandstone foundation..."

\section{RESPONSE}

Response: Page

By: $\quad$ K. Lambert (TAC)

Date: 30 August 1995

Comment unclear. "Foundation" not found as indicated.

\section{Plans for Implementation}

None required. 


\section{COMMENT}

Site: Slick Rock, Colorado

Date: 8 April 1994

Document: Final Remedial Action Plan

Reviewer: A.M. Banani (RAC)

Comment: 17; Attachment 4, Water Resources Protection Strategy, Design Features

Page 2-3, Figure 2.1: Same as Comment No. 2.

\section{RESPONSE}

Response: Page

By: K. Lambert (TAC)

Date: 30 August 1995

Comment acknowledged. See response to Comment No. 2.

Plans for Implementation

Bar scale was corrected. 


\section{COMMENT}

Site: Slick Rock, Colorado

Date: 8 April 1994

Document: Final Remedial Action Plan

Reviewer: A. M. Banani (RAC)

Comment: 18; Attachment 4, Water Resources Protection Strategy, Design Features

Page 2-5, Figure 2.2: Same as Comment No. 3.

\section{RESPONSE}

Response: Page

By: $\quad$ K. Lambert (TAC)

Date: 30 August 1995

Comment acknowledged. See response to Comment No. 3.

Plans for Implementation

The figure was corrected as requested. 


\section{COMMENT}

Site: Slick Rock, Colorado

Date: 8 April 1994

Document: Final Remedial Action Plan

Reviewer: A. M. Banani (RAC)

Comment: 19; Attachment 4, Water Resources Protection Strategy

Page 2-4, 2nd sentence from top of the page: Same as Comment No. 14

\section{RESPONSE}

Response: Page

By: J. Crain (TAC)

Date: 13 June 1994

The buffer area is defined as the difference between the area occupied by the disposal cell and the area permanently withdrawn from public use.

Plans for Implementation

None. 


\section{COMMENT}

Site: Slick Rock, Colorado

Date: 8 April 1994

Document: Final Remedial Action Plan

Reviewer: A. M. Banani (RAC)

Comment: 20, Attachment 4, Water Resources Protection Strategy

Page 3-9, Figure 3.2: Add an arrow and show the "TOP OF BURRO CANYON FM. AND BASE OF DAKOTA SANDSTONE"

\section{RESPONSE}

Response: Page __ By: K. Lambert (TAC) D__ Date: 30 August 1995

The diagrammatic figure shows the Burro Canyon Formation exposure along the Dolores River Canyon. Dakota Sandstone does not appear in this area.

\section{Plans for Implementation}

None required. 


\section{COMMENT}

Site: Slick Rock, Colorado Date: 8 April 1994

Document: Final Remedial Action Plan

Reviewer: A. M. Banani (RAC)

Comment: 21; Appendix B to Attachment 3, Lithologic Logs

Add test pit and corehole logs from 1993 field investigations at Burro Canyon disposal site to this appendix.

\section{RESPONSE}

Response: Page

By: G. Lindsey (TAC)

Date: 25 May 1994

Comment acknowledged.

Plans for Implementation

The logs were entered into the TAC "Gint" log file and have been included in the appendix. 


\section{COMMENT}

Site: Slick Rock, Colorado

Date: 8 April 1994

Document: Final Remedial Action Plan

Reviewer: A. M. Banani (RAC)

Comment: 22; Attachment 2, Geology Report

Page 3-7, Figure 3.6: Coreholes 604 and 606 are also located along cross Section $D-D$ in Figure 3.3. Please add these coreholes to geologic cross Section $D-D$ in Figure 3.6.

\section{RESPONSE}

Response: Page

By: $\quad$ G. Lindsey (TAC)

Date: 25 May 1994

Comment acknowledged.

Plans for Implementation

The coreholes were added to Section D-D as requested. 


\section{COMMENT}

Site: Slick Rock, Colorado

Date: 13 April 1994

Document: Final Remedial Action Plan

Reviewer: A. M. Banani (RAC)

Comment: 23: Remedial Action Selection Report, Introduction

Page 1-2, History

Suggest adding the following to this section "The first uranium concentrating plant in the world was constructed at the UC site in 1898 by two French chemical scientists, Pouilot and Voilique. The plant was in operation for only a few years before being abandoned.

\section{RESPONSE}

Response: Page

By: J. Crain (TAC)

Date: 13 June 1994

Although some contaminants from the "Curie" mill probably are present at the UC site, the history section of the RAP is primarily about prior activities that created the present conditions at the designated sites. Most of the contamination of the sites by RRM occurred when the mills were operated by Umetco and Shattuck Chemical Company.

\section{Plans for Implementation}

Text was revised as requested. 


\section{COMMENT}

Site: Slick Rock, Colorado

Date: 13 April 1994

Document: Final Remedial Action Plan

Reviewer: R. F. Claire (RAC)

Comment: 24, Remedial Action Selection Report

Page 1-5, Figure 1.2: Site boundary is not the same as limits of windblown and waterborne contamination. There is a contaminated area across the river that is not shown. Show separately, the limits of contaminated and site boundary with two different symbols.

\section{RESPONSE}

Response: Page

By: J. Crain (TAC)

Date: 13 June 1994

Comment acknowledged.

Plans for Implementation

The label "limits of windblown and waterborne contamination" was deleted from Figure 1.2. The RAP text was revised accordingly. 


\section{COMMENT}

Site: Slick Rock, Colorado

Date: 13 April 1994

Document: Final Remedial Action Plan

Reviewer: R. F. Claire (RAC)

Comment: 25, Remedial Action Selection Report

Page 1-6, Figure 1.3:

Site boundary is not the same as limits of windblown and waterborne contamination. Show the two areas with two different symbols.

\section{RESPONSE}

Response: Page

By: J. Crain (TAC)

Date: 13 June 1994

Comment acknowledged.

Plans for Implementation

The label "limits of windblown and waterborne contamination" was deleted from

Figure 1.3, and the RAP text was revised accordingly. 


\section{UMTRA DOCUMENT REVIEW FORM}

\section{COMMENT}

Site: Slick Rock, Colorado

Date: 13 April 1994

Document: Final Remedial Action Plan

Reviewer: R. F. Claire (RAC)

Comment: 26, Remedial Action Selection Report

Page 1-7, Figure 1.4: Suggest showing NC and UC sites also.

\section{RESPONSE}

Response: Page

By: J. Crain (TAC)

Date: 13 June 1994

Comment acknowledged.

\section{Plans for Implementation}

Figure 1.4 (Figure 1.3 of final RAP) was revised to show the approximate locations of the UC and NC sites. 


\section{COMMENT}

Site: Slick Rock, Colorado Date: 13 April 1994

Document: Final Remedial Action Plan

Reviewer: R. F. Claire (RAC)

Comment: 27, Remedial Action Selection Report, Introduction

Page 1-10, fourth paragraph, first and second line: Suggest changing "The remedial action is expected to take 19 months. During the summer of the first year, the sites ..." to "The remedial action is expected to take 25 months. During the first summer, the sites ..."

\section{RESPONSE}

Response: Page

By: J. Crain (TAC)

Date: 13 June 1994

Comment acknowledged.

Plans for Implementation

The text was revised as requested. 


\section{COMMENT}

Site: Slick Rock, Colorado

Date: 13 April 1994

Document: Final Remedial Action Plan

Reviewer: R. F. Claire (RAC)

Comment: 28, Remedial Action Selection Report, Geology

Page 2-5, Section 2.3.1, Bedrock Geology

7th Line: Suggest changing "...and claystone strata of the Burro Canyon Formation." to "... and claystone strata of the lower Dakota Formation and the top of Burro Canyon Formation."

\section{RESPONSE}

Response: Page

By: $\quad$ G. Lindsey (TAC)

Date: 25 May 1994

Comment acknowledged.

Plans for Implementation

The paragraph was revised as requested. 


\section{COMMENT}

Site: Slick Rock, Colorado Date: 13 April 1994

Document: Final Remedial Action Plan

Reviewer: R. F. Claire (RAC)

Comment: 29, Remedial Action Selection Report, Geology

Page 2-7, Section 2.4.1 Geomorphic Stability

1st Paragraph: There are no plans to provide erosion protection at the mesa against encroachment or headward advance. The conditions described in 2 nd and 3rd sentences do not require additional erosion protection. Please delete these sentences.

\section{RESPONSE}

Response: Page _ By: G. Lindsev (TAC) Date: 25 Mav 1994

The statement is still applicable even though the design may not require it. No change to the statement is needed.

Plans for Implementation

None. 


\section{COMMENT}

Site: Slick Rock, Colorado

Date: 13 April 1994

Document: Final Remedial Action Plan

Reviewer: R. F. Claire (RAC)

Comment: 30 , Remedial Action Selection Report, Geotechnical Engineering

Page 3-4, Section 3.2.4, Site Stratigraphy

Disposal Site, 4th Sentence: Same as Comment No. 28.

\section{RESPONSE}

Response: Page

By: J. Crain

Date: 13 June 1994

Comment acknowledged.

Plans for Implementation

The text was revised as requested. 


\section{COMMENT}

Site: Slick Rock, Colorado

Date: 13 April 1994

Document: Final Remedial Action Plan

Reviewer: R. F. Claire (RAC)

Comment: 31, Remedial Action Selection Report. Geotechnical Evaluation

Page 3-6, Table 3.1

1. "Results of slop stability analysis" are not specified by TAD. Please delete superscript "a" from the title of this table.

2. Add a column for "Required Factors of Safety" with superscript "a."

3. Delete footnote "NA - not applicable."

\section{RESPONSE}

Response: Page

By: J. Crain (TAC)

Date: 13 June 1994

Comment acknowledged.

Plans for Implementation

The table was revised as requested. 


\section{COMMENT}

Site: Slick Rock, Colorado

Date: 13 April 1994

Document: Final Remedial Action Plan

Reviewer: R. F. Claire (RAC)

Comment: 32, Remedial Action Selection Report

Page 5-8, Section 5.1.2, Hydraulic and Transport Properties

Last line: Change $8.5 \times 10^{-4} \mathrm{~cm} / \mathrm{s}$ to $8.5 \times 10^{-6} \mathrm{~cm} / \mathrm{s}$.

\section{RESPONSE}

Response: Page _ By: J. Crain (TAC) Date: 13 June 1994

Comment acknowledged.

Plans for Implementation

The hydraulic conductivity value was revised as requested. 


\section{COMMENT}

Site: Slick Rock, Colorado

Date: 13 April 1994

Document: Final Remedial Action Plan

Reviewer: R. F. Claire (RAC)

Comment: 33 , Remedial Action Selection Report

Page 5-31, Section 5.7, Water Resources Protection Strategy Summary

2nd bullet, last sentence: There will not be any liner on side walls of the excavation. Delete this sentence.

\section{RESPONSE}

Response: Page By: M. B. Leaf (TAC) Date: 31 August 1995

Comment acknowledged.

Plans for Implementation

Sentence has been deleted from text as requested. 


\section{COMMENT}

Site: Slick Rock, Colorado

Date: 13 April 1994

Document: Final Remedial Action Plan

Reviewer: R.F. Claire (RAC)

Comment: 34 , Remedial Action Selection Report, Geology

Page 2-1, Section 2.1, Scope of Work, 8th Line: We are not sure if refraction seismic surveys were done. Please check, if not, delete from text.

\section{RESPONSE}

Response: Page __ By: G. Lindsey (TAC) Date: 25 May 1994

The seismic survey was performed at the UC site, not at the Burro Canyon site.

Plans for Implementation

The text was revised as requested. 


\section{UMTRA DOCUMENT REVIEW FORM}

\section{COMMENT}

Site: Slick Rock, Colorado

Date: 13 April 1994

Document: Final Remedial Action Plan

Reviewer: R. F. Claire (RAC)

Comment: 35 , Remedial Action Selection Report

Page 3-10, Section 3.4.3, Construction activities and construction sequence

1. General, 2nd Paragraph, 2nd Sentence: Revise to read "...therefore, collection ditches and waste water retention basin will not be required."

2. Wastewater treatment, 1st Paragraph, 2nd Sentence: Revise to read "Any water remaining in the retention basin may be treated further if a discharge is required."

\section{RESPONSE}

Response: Page

By: J. Crain (TAC)

Date: 13 June 1994

Comment acknowledged.

Plans for Implementation

The text was changed as requested. 


\section{COMMENT}

Site: Slick Rock, Colorado

Date: 13 April 1994

Document: Final Remedial Action Plan

Reviewer: R. F. Claire (RAC)

Comment: 36, Remedial Action Selection Report

Page 4-4, Section 4.3.2, Drainage Ditches

1st Paragraph, 3rd Line: Revise to read ". . . and graded (10 percent max.) to facilitate. .."

\section{RESPONSE}

Response: Page

By: J. Crain (TAC)

Date: 13 June 1994

Comment acknowledged.

Plans for Implementation

The text was revised as requested. 


\section{COMMENT}

Site: Slick Rock, Colorado

Date: 13 April 1994

Document: Final Remedial Action Plan

Reviewer: R. F. Claire (RAC)

Comment: 37 , Remedial Action Selection Report, Radon Attenuation and Site Cleanup

Page 6-6, Figure 6.1

Extent of contamination due to mill tailings shown is incorrect. There is no windblown/waterborne contamination downstream from the UC site or across the river from the NC site. The contaminated area across the river from the UC site is smaller than shown. Please revise the contaminated areas accordingly (see attached figure).

\section{RESPONSE}

Response: Page

By: J. Crain (TAC)

Date: 13 June 1994

The areal extent of contamination depicted on Figure 6.1 is based on results of a 1982 survey conducted by EG\&G. All radiological contamination in the vicinity of the sites, regardless of its source, is shown on Figure 6.1. The purpose of the figure is to show locations where soil concentrations of Ra-226 are greater than $5 \mathrm{pCi} / \mathrm{g}$. Some of the areas shown on Figure 6.1 have not been contaminated by milling or by windblown or waterborne tailings (see Section 6.5).

\section{Plans for Implementation}

None. 


\section{COMMENT}

Site: Slick Rock, Colorado

Date: 18 April 1994

Document: Final Remedial Action Plan

Reviewer: J. T. Kam (MK-F)

\section{Comment: 38 , Attachment 3, Groundwater Hydrology Report, Groundwater Investigations}

Page 3-16, Background Groundwater Quality in the Alluvium-North Continent Site

1st Paragraph: As stated in review Comment No. 49 on Draft RAP, Wells 501 and 686 were used as background wells, but according to Figure 3.1, these two wells are at the edge of the processing site and therefore do not qualify as background wells. Revise accordingly.

\section{RESPONSE}

Response: Page

By: K. Monks (TAC)

Date: 2 February 1994

Wells 501 and 686 (screened on the alluvium) are upgradient and/or crossgradient of the tailings and are expected to be the most representative existing background monitor wells. Additional ground water characterization is not required for the proposed surface remediation (relocation off the site), but may be necessary for the ground water cleanup phase of the UMTRA Project.

\section{Plans for Implementation}

None. 


\section{COMMENT}

Site: Slick Rock, Colorado

Date: 19 April 1994

Document: Final Remedial Action Plan

Reviewer: J.T.Kam (MK-F)

Comment: 39, Attachment 3, Groundwater Hydrology Report, Groundwater Investigations

Page 3-17, Background Groundwater Quality in the Alluvium-Union Carbide Site

1st Paragraph: As stated in review Comment No. 50 on Draft RAP, Mo and $\mathrm{Cr}$ samples were taken from Monitor Well 505 which, according to Figure 3.3, is downgradient of the UC processing site and therefore cannot be qualified as a background well. Revise accordingly.

\section{RESPONSE}

Response: Page

Monitor well 505 is upgradient (southeast) of the tailings. The direction of ground water flow, as shown on Figure 3.3, is to the north. For additional information, see response to Comment No. 49.

Plans for Implementation

None required. 


\section{COMMENT}

Site: Slick Rock, Colorado

Date: 18 April 1994

Document: Final Remedial Action Plan

Reviewer: J. T. Kam (MK-F)

Comment: 40, Attachment 3, Groundwater Hydrology Report, Groundwater Investigations

Page 3-41, 3rd Paragraph under Section 3.2.2 (Geology and Hydrostratigraphy).

As stated in review Comment No. 51 on Draft RAP, the text mentions that there are significant upward vertical gradients in the middle and lower sandstone units underneath the disposal site. Also, on Page 3-45, under Burro Canyon Middle Sandstone Unit it is stated that "groundwater occurs under confined conditions and has an upward hydraulic gradient; the potentiometric surface is approximately $40 \mathrm{ft}$ above the top of the middle sandstone unit". This means that the potentiometric surface is still somewhere in the aquitard separating the upper and middle sandstone units. Additionally, according to Figures 3.12 and 3.18 , there is a downward hydraulic gradient between the upper and middle sandstone units contrary to what the text says. Please clarify the inconsistency.

\section{RESPONSE}

Response: Page _ By: K. Monks (TAC) Date: 2 February 1994

In Groundwater (Freeze \& Cherry, 1979), a confined aquifer is defined as "an aquifer that is confined between two aquitards ... In a confined aquifer, the water level usually rises above the top of the aquifer." This is the case for the middle sandstone unit of the Burro Canyon Formation. As stated in the Slick Rock RAP, the potentiometric surface is approximately $40 \mathrm{ft}$ above the top of the middle sandstone unit (in the middle mudstone unit of the Burro Canyon Formation). Since the water levels are above the top of the middle sandstone unit, an upward hydraulic gradient exists. Approximately 60 to $70 \mathrm{ft}$ of low-permeability mudstone separates the upper and middle sandstone units, forming a confining layer to prohibit downward migration of ground water from the upper sandstone unit.

\section{Plans for Implementation}

None. 


\section{COMMENT}

Site: Slick Rock, Colorado Date: 18 April 1994

Document: Final Remedial Action Plan

Reviewer: J.T.Kam (MK-F)

Comment: 41, Attachment 3, Groundwater Hydrologv Report, Groundwater Investigations

Page 3-45, Under Burro Canyon Middle Sandstone Unit

As stated in review Comment No. 52 on Draft RAP, the text mentions that "Groundwater elevations have remained constant, as shown in Figure 3.19". However, in the figure, for Well 516, there appears to be a significant change in water level elevation between January and April of 1990. The same inconsistency occurs in Figure 3.21 when the text on Page 3-45 under Burro Canvon Lower Sandstone Unit says that "Groundwater elevations have remained constant, as shown in Figure 3.21". Correct text or figures for consistency.

\section{RESPONSE}

Response: Page

The "significant change in water level elevation between January and April 1990" results from slow ground water level recovery following monitor well construction and exemplifies the low hydraulic conductivity of the Burro Canyon Formation sandstone units.

\section{Plans for Implementation}

None required. 


\section{COMMENT}

Site: Slick Rock, Colorado

Date: 19 April 1994

Document: Final Remedial Action Plan

Reviewer: J.T. Kam (MK-F)

Comment: 42, Attachment 4, Water Resources Protection Strategy, Water Resources Protection Strategy Summary

Page 1-1 (5th Paragraph), Page 3-1 (2nd Paragraph) and Page 3-11 (3rd Paragraph):

As stated in review Comment No. 54 on Draft RAP, the text mentions upward vertical hydraulic gradient in the middle sandstone unit beneath the disposal site. This is inconsistent with what Figures 3.16 and 3.18 show in Attachment 3. (See Comment No. 40).

\section{RESPONSE}

Response: Page

By: K. Monks (TAC)

Date: 2 February 1994

In Groundwater (Freeze \& Cherry, 1979), a confined aquifer is defined as "an aquifer that is confined between two aquitards... In a confined aquifer, the water level usually rises above the top of the aquifer." This is the case for the middle sandstone unit of the Burro Canyon Formation. As stated in Attachment 3 of the Slick Rock RAP, the potentiometric surface is approximately $40 \mathrm{ft}$ above the top of the middle sandstone unit (in the middle mudstone unit of the Burro Canyon Formation). Since the water levels are above the top of the middle sandstone unit, an upward hydraulic gradient exists.

\section{Plans for Implementation}

None required. 


\section{COMMENT}

Site: Slick Rock, Colorado

Date: 19 April 1994

Document: Final Remedial Action Plan

Reviewer: J.T.Kam (MK-F)

Comment: 43, Remedial Action Selection Report, Water Resources Protection

Page 5-5, 5th Paragraph, Page 5-18 (4th Paragraph), and Page 5-21 (under proposed concentration limits):

As stated in review Comment No. 55 on Draft RAP, upward gradient in the middle sandstone is questionable. (See Comment No. 40.)

\section{RESPONSE}

Response: Page

By: K. Monks (TAC)

Date: 2 February 1994

In Groundwater (Freeze \& Cherry, 1979), a confined aquifer is defined as "an aquifer that is confined between two aquitards...In a confined aquifer, the water level usually rises above the top of the aquifer." This is the case for the middle sandstone unit of the Burro Canyon Formation. As stated in Attachment 3 of the Slick Rock RAP, the potentiometric surface is approximately $40 \mathrm{ft}$ above the top of the middle sandstone unit (in the middle mudstone unit of the Burro Canyon Formation). Since the water levels are above the top of the middle sandstone unit, an up ward hydraulic gradient exists.

\section{Plans for Implementation}

None required. 
THIS PAGE INTENTIONALLY LEFT BLANK. THERE ARE NO COMMENT NOS. 44, 45, 46, OR 47. 


\section{COMMENT}

Site: Slick Rock, Colorado

Date: 19 April 1994

Document: Final Remedial Action Plan

Reviewer: J. T. Kam (MK-F)

Comment: 48, Attachment 3, Groundwater Hydrology Report, Groundwater Investigations

Page 3-6, Groundwater Conditions in the Entrada Formation

1st sentence should refer to the Union Carbide processing site only.

\section{RESPONSE}

Response: Page

By: K. Monks (TAC)

Date: 2 February 1994

Comment acknowledged.

Plans for Implementation

The text was revised as requested. 


\section{COMMENT}

Site: Slick Rock, Colorado

Date: 19 April 1994

Document: Final Remedial Action Plan

Reviewer: J.T.Kam (MK-F)

Comment: 49, Attachment 3, Ground water Hydrology Report, Groundwater Investigations

Page 3-12, Background Ground water Quality in the Alluvium North Continent Site

1st paragraph: Wells 501 and 686 were used as background wells, but according to Figure 3.1, these two wells are at the edge of the processing site and therefore do not qualify as background wells. Revise accordingly.

\section{RESPONSE}

Response: Page __ By: K. Monks (TAC) Date: 2 February 1994

Wells 501 and 686 (screened in the alluvium) are upgradient and/or crossgradient of the tailings and are expected to be the most representative existing background monitor wells. Additional ground water characterization is not required for the proposed surface remediation (relocation off the site) but may be necessary for the ground water cleanup phase of the UMTRA Project.

Plans for Implementation

None. 


\section{UMTRA DOCUMENT REVIEW FORM}

\section{COMMENT}

Site: Slick Rock, Colorado

Date: 19 April 1994

Document: Final Remedial Action Plan

Reviewer: J. T. Kam (MK-F)

Comment: 50, Attachment 3, Groundwater Hydrology Report, Groundwater Investigations

Page 3-13, Background Groundwater Quality in the Alluvium - Union Carbide Site

1st paragraph: Mo and $\mathrm{Cr}$ samples were taken from Monitor Well 505 which, according to Figure 3.3, is downgradient of the UC processing site and therefore cannot be qualified as a background well. Revise accordingly.

\section{RESPONSE}

Response: Page __ By: K. Monks (TAC) ___ Date: 2 February 1994

Monitor well 505 is upgradient (southeast) of the tailings. The direction of ground water flow, as shown on Figure 3.3, is to the north. For additional information, see response to Comment No. 49.

Plans for Implementation

None. 


\section{COMMENT}

Site: Slick Rock, Colorado Date: 19 April 1994

Document: Final Remedial Action Plan

Reviewer: J. T, Kam (MK-F)

\section{Comment: 51, Attachment 3, Ground water Hydrology Report, Ground water Investigations}

Page 3-36, 3rd Paragraph under Section 3.2.2 (Geology and Hydrostratigraphy)

The text mentions that there are significant upward vertical gradients in the middle and lower sandstone units underneath the disposal site. Also, on Page 3-38, under Burro Canyon Middle Sandstone Unit it is stated that "ground water occurs under confined conditions and has an upward hydraulic gradient; the potentiometric surface is approximately $40 \mathrm{ft}$ above the top of the middle sandstone unit". This means that the potentiometric surface is still somewhere in the aquitard separating the upper and middle sandstone units. Additionally, according to Figures 3.12 and 3.14 , there is a downward hydraulic gradient between the upper and middle sandstone units contrary to what the text says. Please clarify the inconsistency.

\section{RESPONSE}

Response: Page __ By: K. Monks (TAC) Date: 2 February 1994

In Groundwater (Freeze \& Cherry, 1979), a confined aquifer is defined as "an aquifer that is confined between two aquitards ... In a confined aquifer, the water level usually rises above the top of the aquifer." This is the case for the middle sandstone unit of the Burro Canyon Formation. As stated in the Slick Rock RAP, the potentiometric surface is approximately $40 \mathrm{ft}$ above the top of the middle sandstone unit (in the middle mudstone unit of the Burro Canyon Formation). Since the water levels are above the top of the middle sandstone unit, an upward hydraulic gradient exists. Approximately 60 to $70 \mathrm{ft}$ of.low-permeability mudstone separates the upper and middle sandstone units, forming a confining layer to prohibit downward migration of ground water from the upper sandstone unit.

\section{Plans for Implementation}

None. 


\section{COMMENT}

Site: Slick Rock, Colorado Date: 19 April 1994

Document: Final Remedial Action Plan

Reviewer: J.T.Kam (MK-F)

Comment: 52 , Attachment 3, Ground water Hydrology Report, Groundwater Investigations

Page 3-38, Under Burro Canyon Middle Sandstone Unit

The text mentioned that "Groundwater elevations have remained constant, as shown in Figure 3.15". However, in the Figure, for Well 516, there appears to be a significant change in water level elevation between January and April of 1990. The same inconsistency occurs in Figure 3.17 when the text on Page 3-38 under Burro Canyon Lower Sandstone Unit says that "Groundwater elevations have remained constant, as shown in Figure 3.17". Correct text or figures for consistency.

\section{RESPONSE}

Response: Page

By: K. Monks (TAC)

Date: 2 February 1994

The "significant change in water level elevation between January and April 1990" results from slow ground water level recovery following monitor well construction and exemplifies the low hydraulic conductivity of the Burro Canyon Formation sandstone units.

\section{Plans for Implementation}

None. 


\section{COMMENT}

Site: Slick Rock, Colorado

Date: 19 April 1994

Document: Final Remedial Action Plan

Reviewer: J. T. Kam (MK-F)

Comment: 53, Attachment 3, Ground water Hydrology Report, Groundwater Investigations

Page 3-47, under Burro Canyon Upper Sandstone Unit

Figure 3.11 referred to in the 2 nd sentence should have been Figure 3.12. Likewise on Page 3-48, Figure 3.11 under Burro Canyon Middle Sandstone Unit should have been Figure 3.14 and Figure 3.11 under Burro Canvon Lower Sandstone unit should have been Figure 3.16 .

\section{RESPONSE}

Response: Page

By: K Monks (TAC)

Date: 2 February 1994

Comment acknowledged.

Plans for Implementation

The figure numbers were modified as requested. 


\section{COMMENT}

Site: Slick Rock, Colorado Date: 19 April 1994

Document: Final Remedial Action Plan

Reviewer: J.T.Kam (MK-F)

Comment: 54, Attachment 4, Water Resources Protection Strategy, Water Resources Protection Strategy Summary

Page 1-1, (5th Paragraph), Page 3.1 (2nd Paragraph) and Page 3-10 (3rd Paragraph).

The text mentions upward vertical gradients in the middle sandstone unit beneath the disposal site. This is inconsistent with what Figures 3.12 and 3.14 show in Attachment 3 (see Comment 51).

\section{RESPONSE}

Response: Page

In Groundwater (Freeze \& Cherry, 1979), a confined aquifer is defined as "an aquifer that is confined between two aquitards... In a confined aquifer, the water level usually rises above the top of the aquifer." This is the case for the middle sandstone unit of the Burro Canyon Formation. As stated in Attachment 3 of the Slick Rock RAP, the potentiometric surface is approximately $40 \mathrm{ft}$ above the top of the middle sandstone unit (in the middle mudstone unit of the Burro Canyon Formation). Since the water levels are above the top of the middle sandstone unit, an upward hydraulic gradient exists.

\section{Plans for Implementation}

None. 


\section{COMMENT}

Site: Slick Rock, Colorado

Document: Final Remedial Action Plan

Reviewer: J. T. Kam (MK-F)

Comment: 55, Attachment 4, Water Resources Protection Strategy, Water Resources Protection Strategy Summary

Page 5-5, 4th Paragraph, Page 5.18 (2nd Paragraph), and Page 5-21 (under proposed concentration limits), upward gradient in the middle sandstone is questionable. See Comment 51.

\section{RESPONSE}

Response: Page

By: K. Monks (TAC)

Date: 2 February 1994

In Groundwater (Freeze \& Cherry, 1979), a confined aquifer is defined as "an aquifer that is confined between two aquitards... In a confined aquifer, the water level usually rises above the top of the aquifer.". This is the case for the middle sandstone unit of the Burro Canyon Formation. As stated in Attachment 3 of the Slick Rock RAP, the potentiometric surface is approximately $40 \mathrm{ft}$ above the top of the middle sandstone unit (in the middle mudstone unit of the Burro Canyon Formation). Since the water levels are above the top of the middle sandstone unit, an upward hydraulic gradient exists.

\section{Plans for Implementation}

None. 


\section{COMMENT}

Site: Slick Rock, Colorado Date: 19 April 1994

Document: Final Remedial Action Plan

Reviewer: J. T. Kam (MK-F)

Comment: 56, Attachment 4, Water Resources Protection Strategy, Conceptual Design Considerations and Features for Water Resources Protection

On Page 2-4, Section 2.2.2 mentions the tailings have a saturated hydraulic conductivity of about $5 \times 10^{-2} \mathrm{~cm} / \mathrm{s}$ and that the Dakota Sandstone foundation has a saturated $\mathrm{K}$ of about $1.5 \times 10^{-4} \mathrm{~cm} / \mathrm{s}$ (page 2-2 under Section 2.1.3). Based on these values, there is a potential for water to back up in the bottom of the cell during transient drainage of construction water trapped in the tailings. Suggest that a performance assessment be conducted to evaluate the flooding possibility.

\section{RESPONSE}

Response: Page

By: K. Monks (TAC)

Date: 2 February 1994

Comment acknowledged. The results have been presented in a water balance calculation which is included in Appendix $C$ to Attachment 3, Calculation No. SRK-1 1-94-14-09-00.

\section{Plans for Implementation}

Attachment 4, Section 3.3, was modified to summarize the results of the seepage report. 


\section{COMMENT}

Site: Slick Rock, Colorado Date: 19 April 1994

Document: Final Remedial Action Plan

Reviewer: J. T. Kam (MK-F)

Comment: 57, Attachment 4, Water Resources Protection Strategy, Disposal and Control of Radioactive Materials and Nonradioactive Contaminants

According to Figure 3.1 on Page 3-8, not the entire stretch of the Joe Davis Canyon is crossgradient from the Burro Canyon disposal cell as mentioned on Page 3-7 under Surface Points of Exposure. A section through the disposal cell and the Joe Davis Canyon probably would help to clarify the picture.

\section{RESPONSE}

Response: Page

By: K. Monks (TAC)

Date: 2 February 1994

The RAC and TAC have conducted several field investigations (i.e., installation of coreholes, monitor wells, and test pits) at the Burro Canyon disposal site; however, these do not extend a mile away from the site to Joe Davis Canyon. As a result, Figures 3.1 and 3.2 were modified from a USGS professional paper (Shawe, 1968), based on his investigation and research, and must be presented in that context. The upper sandstone unit is discontinuous, as shown in Figure 3.2. However, since the subsurface extent of the upper sandstone unit has not been fully investigated and mapped by the RAC or TAC, we must rely on the USGS report.

\section{Plans for Implementation}

None. 


\section{COMMENT}

Site: Slick Rock, Colorado Date: 1 August 1995

Document: Final Remedial Action Plan

Reviewer: A.M. Banani (RAC)

Comment: 58, General Comment

1. Radon barrier materials come from the Burro Canyon disposal cell excavation. Laboratory test results for this material is presented in MKES Calculation Nos. 11-340-01-00 and 11-340-02-00. Disappointment Valley borrow source is no longer a source for radon barrier material. Please delete all references to the Disappointment Valley borrow source found in the document.

2. According to MKES Calculation No. 11-340-02-00, the thickness of radon barrier material is $1.5 \mathrm{ft}$. The new design thickness is based on the physical and radiological properties of the materials from the required excavation at the $B C$ site. Please change the thickness of the radon barrier from $2^{\prime}$ to $1.5^{\prime}$ throughout the document.

\section{RESPONSE}

Response: Page By: M. B. Leaf (TAC) Date: 12 August 1995

Comment acknowledged.

Plans for Implementation

Comment was incorporated as requested. 


\section{COMMENT}

Site: Slick Rock, Colorado

Date: 1 August 1995

Document: Final Remedial Action Plan

Reviewer: A. M. Banani (RAC)

Comment: 59 , Remedial Action Selection Report

Page 3-9, Section 3.4.1, 8th bullet:

Change "...at or near the optimum moisture content,..." to "at or above optimum moisture content,..."

\section{RESPONSE}

Response: Page

By: M. B. Leaf (TAC)

Date: 12 Auqust 1995

Comment acknowledged.

Plans for Implementation

Comment was incorporated as requested. 


\section{COMMENT}

Site: Slick Rock, Colorado Date: 1 August 1995

Document: Final Remedial Action Plan

Reviewer: A. M. Banani (RAC)

Comment: 60, Remedial Action Selection Report

Page 3-9, Section 3.4.1, 4th, 7th, and 8th bullet:

Delete "(ASTM, 1991)."

\section{RESPONSE}

Response: Page

Comment acknowledged.

Plans for Implementation

Comment was incorporated as requested. 


\section{COMMENT}

Site: Slick Rock, Colorado

Date: 1 August 1995

Document: Final Remedial Action Plan

Reviewer: A.M. Banani (RAC)

Comment: 61, Remedial Action Selection Report

Page 6-2, 1st paragraph.

See Comment No. 1.

\section{RESPONSE}

Response: Page

By: M. B. Leaf (TAC)

Date: 12 August 1995

Comment acknowledged.

Plans for Implementation

Comment was incorporated as requested. 


\section{COMMENT}

Site: Slick Rock, Colorado Date: 1 August 1995

Document: Final Remedial Action Plan

Reviewer: A. M. Banani (RAC)

Comment: 62, Remedial Action Selection Report

Page 3-10, Section 3.4.3:

1. 4th paragraph, 4th sentence: Change "in conjunction with the volume in the basin due to the average..." to "in conjunction with the maximum accumulated runoff volume in the basin due to the average..."

2. 5th paragraph, 3rd sentence: Change "...and the water surface." to "...and the maximum water surface."

\section{RESPONSE}

Response: Page

By: M. B. Leaf (TAC)

Date: 12 August 1995

Comment acknowledged.

Plans for Implementation

Comment was incorporated as requested. 


\section{COMMENT}

Site: Slick Rock, Colorado

Date: 1 August 1995

Document: Final Remedial Action Plan

Reviewer: A. M. Banani (RAC)

Comment: 63 , Remedial Action Selection Report

Page ES-1, Remedial Action

3rd paragraph, 6th sentence: There is no plan to excavate 39 feet into mudstone of the Burro Canyon Formation. Revise the sentence to read "The mudstone/claystone of the Burro Canyon Formation will provide a natural impermeable barrier from the base of the disposal cell to at least $7 \mathrm{ft}$ up the side wall to form a continuous...."

\section{RESPONSE}

Response: Page

By: $\quad$ M. B. Leaf (TAC)

Date: 13 August 1995

As stated in the response to CDPHE Comment No. 1, the DOE has agreed to a 45- to $50-\mathrm{ft}$ excavation at the deep end of the cell that is 20 to $36 \mathrm{ft}$ below the Dakota Sandstone/Burro Canyon Formation interface. This will result in a minimum $7-\mathrm{ft}$ sidewall liner throughout the cell and a 20- to 39-ft "liner effect" at the deep end of the cell.

\section{Plans for Implementation}

None. 


\section{COMMENT}

Site: Slick Rock, Colorado

Date: 1 August 1995

Document: Final Remedial Action Plan

Reviewer: A.M. Banani (RAC)

Comment: 64, Remedial Action Selection Report

Page 1-12, Table 1.2

1. Calculation Nos. 11-321-01-00 and 11-321-02-01 have been superseded. Replace with Calculation Nos. 11-340-01-00 and 11-340-02-00 respectively. These new calculations are for radon barrier design using materials from required excavation at $\mathrm{BC}$ site.

2. Change Calculation No. "11-320-01-00" to "11-310-01-00."

3. Under "Remark," for settlement and cover cracking, add "There is no potential or cover cracking due to differential settlement."

4. Change radon barrier thickness from $2 \mathrm{ft}$ to $1.5 \mathrm{ft}$.

\section{RESPONSE}

Response: Page

By: M. B. Leaf (TAC)

Date: 26 August 1995

Comment acknowledged.

Plans for Implementation

Comment was incorporated as requested. 


\section{COMMENT}

Site: Slick Rock, Colorado

Date: 1 August 1995

Document: Final Remedial Action Plan

Reviewer: A.M. Banani (RAC)

Comment: 65, Remedial Action Selection Report, Radon Attentuation and Site Cleanup

Page 3-2, Borrow areas:

Delete 6th sentence. See Comment No. 1.

\section{RESPONSE}

Response: Page By: M. B. Leaf (TAC)

Date: 12 August 1995

Comment acknowledged.

Plans for Implementation

Comment was incorporated as requested. 


\section{COMMENT}

Site: Slick Rock, Colorado

Date: 1 August 1995

Document: Final Remedial Action Plan

Reviewer: A. M. Banani (RAC)

Comment: 66, Remedial Action Selection Report

Page 5-31, 2nd bullet, last sentence.

Same as Comment No. 7.

\section{RESPONSE}

Response: Page

Comment acknowledged.

Plans for Implementation

Comment was incorporated as requested. 


\section{COMMENT}

Site: Slick Rock, Colorado

Date: 1 August 1995

Document: Final Remedial Action Plan

Reviewer: A.M. Banani (RAC)

Comment: 67, Attachment 3, Ground Water Hydrology Report

Page 3-36, under 3.1.8 Geochemical Conditions

In the 5th paragraph, monitor well 503 is right at the tailings pile of the NC site rather than in the immediately downgradient of the tailings piles (See Figure 3.3).

\section{RESPONSE}

Response: Page

By: M. B. Leaf (TAC)

Date: 12 August 1995

Comment acknowledged.

Plans for Implementation

Comment was incorporated as requested. 


\section{COMMENT}

Site: Slick Rock, Colorado Date: 1 August 1995

Document: Final Remedial Action Plan

Reviewer: A. M. Banani (RAC)

Comment: 68, Attachment 3, Ground Water Hydrology Report

Page 3-40

Figure 3.14 does not have a directional north arrow. Same problem occurs in Figures $3.16,3.18$ and 3.20 on Pages $3-44,3-46$ and $3-48$, respectively.

\section{RESPONSE}

Response: Page _ By: M. B. Leaf (TAC) ___ Date: 12 August 1995

Comment acknowledged.

Plans for Implementation

Comment was incorporated as requested. 


\section{COMMENT}

Site: Slick Rock, Colorado

Date: 1 August 1995

Document: Final Remedial Action Plan

Reviewer: A. M. Banani (RAC)

Comment: 69 , Remedial Action Selection Report

Page 6-4, Evaluation of Radon Barrier

The data presented here are for radon barrier material using Disappointment Valley borrow source. See Comment No. 1 and revise accordingly.

\section{RESPONSE}

Response: Page

Comment acknowledged.

Plans for Implementation

Comment was incorporated as requested. 


\section{UMTRA DOCUMENT REVIEW FORM}

\section{COMMENT}

Site: Slick Rock, Colorado

Date: 1 August 1995

Document: Final Remedial Action Plan

Reviewer: A. M. Banani (RAC)

Comment: 70, Attachment 4, Water Resources Protection Strategy

Page 2-2

1. 2nd Paragraph, 6th Sentence: Add "is" after "Dakota Sandstone."

2. Section 2.2, Design Features: Same as Comment No. 7.

\section{RESPONSE}

Response: Page

By: M. B. Leaf (TAC)

Date: 12 August 1995

Comment acknowledged.

Plans for Implementation

Comment was incorporated as requested. 


\section{COMMENT}

Site: Slick Rock, Colorado Date: 7 August 1995

Document: Final Remedial Action Plan

Reviewer: J.T.Kam (MK-F)

Comment: 71, Attachment 3, Ground Water Hydrology Report

Page 3-15 under Navajo Sandstone Formation

The calculated average linear ground water velocity in the Navajo Sandstone should be $5.8 \times 10^{-1} \mathrm{ft} /$ year instead of $1 \mathrm{ft} /$ year, based on an average hydraulic conductivity of $2.4 \times 10^{-2} \mathrm{ft} /$ day under a hydraulic gradient of 0.02 and an estimated effective porosity of 0.30 .

\section{RESPONSE}

Response: Page

By: K. Lambert (TAC)

Date: 21 August 1995

Comment acknowledged.

Plans for Implementation

Text was corrected as requested. 


\section{COMMENT}

Site: Slick Rock, Colorado Date: 7 Auqust 1995

Document: Final Remedial Action Plan

Reviewer: J. T. Kam (MK-F)

Comment: 72, Attachment 3, Ground Water Hydrology Report

Page 3-41 under 3.2.2, Geology and Hydrostratigraphy

End of 3rd paragraph states "even if seepage from the disposal cell occurred, the upward vertical gradients would prohibit potential seepage from migrating below the upper sandstone unit." This statement is not true because the potentiometric surface of the middle sandstone unit is lower than that of the upper sandstone unit (see 4th paragraph on Page 3-52) and therefore, there is a potential for leakage from the upper to lower sandstone unit. This differential head is also reflected by comparing the potentiometric heads of the upper and middle sandstone units in Figures 3.16 and 3.18 .

\section{RESPONSE}

Response: Page

Comment acknowledged.

\section{Plans for Implementation}

Text was amended to indicate that low-permeability mudstone inhibits the potential downward migration of ground water from the upper sandstone unit. 


\section{COMMENT}

Site: Slick Rock, Colorado

Date: 7 August 1995

Document: Final Remedial Action Plan

Reviewer: J.T.Kam (MK-F)

Comment: 73, Attachment 3, Ground Water Hydrology Report

Page 3-42

Figure 3.15 does not include the location of the tailings piles and also does not refer to where this $x$-section is cutting through, for example, in Figure 3.14.

\section{RESPONSE}

Response: Page

By: M. B. Leaf (TAC)

Date: 12 August 1995

Comment acknowledged.

Plans for Implementation

Comment was incorporated as requested. 


\section{UMTRA DOCUMENT REVIEW FORM}

\section{COMMENT}

Site: Slick Rock, Colorado Date: 7 August 1995

Document: Final Remedial Action Plan

Reviewer: J.T.Kam (MK-F)

Comment: 74, Attachment 3, Ground Water Hydrology Report

Pages 3-50 and 3-51, under Burro Canyon Upper Sandstone Unit

The following questions are posed regarding hydraulic testing of the upper sandstone unit:

1. Is wellbore storage effect taken into consideration in the analysis?

2. How was the storage coefficient of 0.1 derived since there were no drawdown at any observation wells? Was this assumed?

3. The storage coefficient of 0.1 indicates that an unconfined condition exists. Was the Theis nonequilibrium well equation adjusted in the analysis to accommodate the unconfined condition?

\section{RESPONSE}

Response: Page

By: K. Lambert (TAC)

Date: 21 August 1995

See Calculation No. SRK-06-91-14-03-00 in Appendix C to Attachment 3, for method and procedures, and assumptions.

Plans for Implementation

None required. 


\section{COMMENT}

Site: Slick Rock, Colorado

Date: 7 August 1995

Document: Final Remedial Action Plan

Reviewer: J.T. Kam (MK-F)

Comment: 75, Attachment 3, Ground Water Hydrology Report

Page 3.52 under Burro Canyon Lower Sandstone Unit

Was borehole storage considered during the analysis of aquifer testing for the lower sandstone unit?

\section{RESPONSE}

Response: Page

By: K. Lambert (TAC)

Date: 21 August 1995

See response to Comment No. 74 .

Plans for Implementation

None required. 


\section{COMMENT}

Site: Slick Rock, Colorado Date: 7 August 1995

Document: Final Remedial Action Plan

Reviewer: J.T.Kam (MK-F)

Comment: 76, Response to Previous Comment Nos. 51, 54, and 55, Attachment 3, Ground Water Hydrology Report

\section{Page 48}

The significance of mentioning a vertical gradient here is to assess the potential of downward migration of ground water between the upper and middle sandstone units. The argument is not on the gradient within the aquifer itself but between aquifers. There may be local upward gradient within the middle sandstone, but in a global view, there is a downward hydraulic gradient between the upper and middle sandstone units. This implies a potential of leakage from the upper to the middle units. However, we may say there is a tendency for the low-permeability mudstone to prohibit downward migration of groundwater from the upper sandstone unit.

\section{RESPONSE}

Response: Page

See response to Comment No. 72 .

Plans for Implementation

None required. 


\section{COMMENT}

Site: Slick Rock, Colorado Date: 7 August 1995

Document: Final Remedial Action Plan

Reviewer: J.T. Kam (MK-F)

Comment: 77, Response to Previous Comment No. 52, Attachment 3, Ground Water Hydrology Report

Page 3-43, under Burro Canyon Middle Sandstone Unit

Sentence should be modified to "Ground water elevations have remained constant except between January and April 1990, when a significant change in water level elevation resulted from slow ground water level recovery following monitor well construction and exemplified the low hydraulic conductivity of the Burro Canyon Sandstone Unit.

\section{RESPONSE}

Response: Page

Comment acknowledged.

Plans for Implementation

Text was revised as requested. 


\section{UMTRA DOCUMENT REVIEW FORM}

\section{COMMENT}

Site: Slick Rock, Colorado Date: 8 August 1995

Document: Final Remedial Action Plan

Reviewer: R. F. Claire (RAC)

Comment: 78, Response to Previous Comment, Remedial Action Report Selection Report

Page 5-16, Section 5.1.5, Water Use at Processing Site

1st paragraph - There is no longer a post office at Slick Rock. In addition the water supply for the restaurant and trailers is from a private well.

\section{RESPONSE}

Response: Page

By: M. B. Leaf

Date: 12 August 1995

Comment acknowledged.

Plans for Implementation

Text was revised as requested. 


\section{COMMENT}

Site: Slick Rock, Colorado Date: 8 Auqust 1995

Document: Final Remedial Action Plan

Reviewer: R. F. Claire (RAC)

Comment: 79, Response to Previous Comment, Remedial Action Report Selection Report

Page 5-6, Figure 5.3

Add MK boreholes to plan.

\section{RESPONSE}

Response: Page

By: M. B. Leaf (TAC)

Date: 12 August 1995

Comment acknowledged.

Plans for Implementation

Comment was incorporated as requested. 


\section{COMMENT}

Site: Slick Rock, Colorado

Date: 8 August 1995

Document: Final Remedial Action Plan

Reviewer: R. F. Claire (RAC)

Comment: 80 , Response to Previous Comment, Water Resources Protection Strategy

Page 2-6, Section 2.2.2

Prior to the last sentence add "The final depth of the excavation and height of the impermeable layer will be verified by geologist prior to placing tailings."

\section{RESPONSE}

Response: Page

Comment acknowledged.

Plans for Implementation

Change was made as requested. 


\section{COMMENT}

Site: Slick Rock, Colorado

Date: 8 Auqust 1995

Document: Final Remedial Action Plan

Reviewer: R. F. Claire (RAC)

Comment: 81, Remedial Action Selection Report

Page 2-7, Section 2.4.1, Geomorphic Stability

1st paragraph. Replace the last sentence with the following:

"The central drainage exit at the south side of the mesa should not be overlapped by the cell. The gully should be backfilled with material from the cell excavation to provide additional protection against headward advance of this tributary."

The above reflects what the actual design is and does not leave an open issue as to what kind or type of erosion protection is required.

\section{RESPONSE}

Response: Page By: $\quad$ M. B. Leaf (TAC)

Date: 12 August 1995

Comment acknowledged.

Plans for Implementation

Comment was incorporated as requested. 


\section{COMMENT}

Site: Slick Rock, Colorado Date: 8 August 1995

Document: Final Remedial Action Plan

Reviewer: R.F. Claire (RAC)

Comment: 82, Response to Previous Comment, Remedial Action Selection Report

Page 1-2, Section 1.2.1, History, Add

Add "Prior to the 1957 operations, one of the first uranium mills was in operation around the turn of the century. While there are no tailings, there is some radiological contamination associated with this mill."

\section{RESPONSE}

Response: Page

By: M. B. Leaf $(T A C)$

Date: 27 August 1995

Comment acknowledged.

Plans for Implementation

Text was revised. 


\section{COMMENT}

Site: Slick Rock, Colorado Date: 8 August 1995

Document: Final Remedial Action Plan

Reviewer: R.F. Claire (RAC)

Comment: 83 , Response to Previous Comment, Remedial Action Selection Report

1. Page ES-2, Ground Water Compliance, 17th line: The stand pipes will not be installed at the toe of the disposal cell. Revise to read: “...stand pipes will be installed to the bottom of the disposal cell..."

2. Page 5-29, Ground Water Monitoring, 15th line: Same as No. 1 above.

\section{RESPONSE}

Response: Page

By: M. B. Leaf (TAC)

Date: 12 August 1995

Comment acknowledged.

Plans for Implementation

Comment was incorporated as requested. 


\section{COMMENT}

Site: Slick Rock, Colorado

Date: 1 August 1995

Document: Final Remedial Action Plan

Reviewer: A. M. Banani (RAC)

Comment: 84 , Remedial Action Selection Report

Page 6-2, Section 6.3.2, Radon Diffusion

The data presented for radon barrier in this section is for the material from

Disappointment Valley borrow source. Use the data for the material from excavation in $\mathrm{BC}$ site. See Comment No. 1.

\section{RESPONSE}

Response: Page

Comment acknowledged.

Plans for Implementation

Text was revised as requested. 


\section{COMMENT}

Site: Slick Rock, Colorado

Date: 8 August 1995

Document: Final Remedial Action Plan

Reviewer: R. F. Claire (RAC)

Comment: 85, Attachment 2, Geology Report, Appendix A

After Page 6-11

The calculation should be checked and approved and all pages should be titled, dated and initialed. Suggest the calculation be removed from the Geology Report and inserted in the calculation volumes or elsewhere.

\section{RESPONSE}

Response: Page By: J. Crain (TAC) Date: 30 August 1995

Comment acknowledged.

\section{Plans for Implementation}

The calculation was written, checked, and approved in accordance with the procedure in place in 1990. Through error of omission, the original approval sheet was not included in the preliminary final document, but has been included in this revision of the document. The present location of Calculation No. SRK-04-90-0303-00 (the appendix to Attachment 2, Geology Report) will remain unchanged as the calculation was prepared in response to a comment regarding the geology section of the document, not ground water hydrology, where the document's other calculations are presently located. 